\title{
A Ordem
}

\section{Econômico-Comercial}

Internacional: Uma

Análise da Evolução

do Sistema

Multilateral de

Comércio e da

Participação da

Diplomacia

\section{Econômica Brasileira no Cenárío Mundial*}

Ivan Tiago Machado Oliveira**

\section{Introdução}

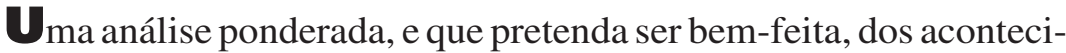
mentos contemporâneos exige o conhecimento dos processos históricos que formaram o caminho seguido até o presente. Isto é, ao analisarmos o comportamento dos agentes ao longo dos anos precedentes - a história da interação entre eles -, os argumentos a serem utili-

\footnotetext{
*Artigo recebido em outubro e aprovado para publicação em novembro de 2006.

**Mestrando em Administração pela Universidade Federal da Bahia (UFBA) e pesquisador do Laboratório de Análise Política Mundial (Labmundo) da Escola de Administração da UFBA.
}

CONTEXTO INTERNACIONAL Rio de Janeiro, vol. 29, n² 2, julho/dezembro 2007, p. 217-272. 
zados acerca do cenário atual ganham maior embasamento e consistência analítica. Assim, realizaremos, no presente estudo, uma avaliação do processo evolutivo ocorrido no Sistema Multilateral de Comércio (SMC), desde o imediato pós-Segunda Guerra até o presente momento, identificando as interações entre as transformações históricas mundiais, tanto no plano político quanto no econômico, e a estruturação do sistema multilateral.

O SMC contemporâneo tem suas bases constitutivas na Carta que criava a natimorta Organização Internacional do Comércio (OIC), da qual o Acordo Geral sobre Tarifas e Comércio (em inglês, General Agreement on Tariffs and Trade (GATT)) faria parte. O GATT, estabelecido em 1947 para atuar temporariamente, acabou por ser o organismo (quase-instituição) responsável pela regulação das trocas internacionais por quase cinco décadas. Nesse ínterim, ocorreram modificações significativas na economia mundial, afetando a competitividade das nações e modificando o jogo da política internacional.

Uma rápida avaliação do histórico do sistema multilateral sob os auspícios do GATT nos trará alguns elementos comprobatórios de que o lançamento periódico de rodadas de negociação se fundamenta na crença de que as mesmas são importante mecanismo para a criação de um ambiente mais propício ao debate político-diplomático, tendendo a ser observada uma melhora apreciável na facilitação do processo político de construção de regras para o comércio internacional. Ocorreram oito rodadas de negociações no âmbito do GATT. Nessas rodadas, tanto as reformas do próprio GATT quanto os processos de mudança nas barreiras comerciais das partes contratantes eram discutidos. As oito rodadas foram: em Genebra (1947), Annecy (1949), Torquay (1951), Genebra (1956), a chamada Rodada Dillon (1960-1961), a Rodada Kennedy (1964-1967), a Rodada Tóquio (1973-1979) e a chamada Rodada Uruguai (1986-1994).

Tomando tais rodadas de negociação multilateral como marcos analíticos importantes, discutiremos, a seguir, o desenrolar do processo 
A Ordem Econômico-Comercial Internacional: Uma Análise da Evolução do Sistema...

histórico-evolutivo do SMC, que teve seus fundamentos teóricos originados em uma visão liberal acerca do comércio internacional, além de aspectos outros de ordem político-ideológica. Primeiramente, analisaremos os esforços de construção do SMC desde a Carta de Havana até os anos 1960, quando acontece a Rodada Kennedy de negociações do GATT. Em seguida, serão abordadas as transformações no sistema, ocorridas na Rodada Tóquio e alargadas na Rodada Uruguai. Finalmente, concluiremos o capítulo analisando o SMC na última década, período marcado pela entrada em cena da Organização Mundial do Comércio (OMC) como verdadeira instituição internacional responsável pela regulação, discussão e abertura de negociação multilateral no que diz respeito às trocas entre as nações. Ademais, o papel desempenhado pela diplomacia econômica brasileira na construção e transformação do SMC será discutido ao longo do presente capítulo.

\section{Da Carta de Havana à Rodada Kennedy}

\section{O Problema da regulação do comércio internacional no pós-Segunda Guerra}

Ao fim da Segunda Guerra Mundial, iniciou-se a reconstrução econômica internacional, fundamentada nas novas relações de poder político-econômico que a guerra ajudara a criar. Entretanto, a reconstrução econômica do pós-guerra não deve ser entendida somente a partir do cenário então vigente, mas também como reorientação e reorganização das relações econômicas internacionais, no contexto pós-depressão dos anos 1930.

A explosão da crise econômica da década de 1930 fez com que o protecionismo tomasse a cena internacional, afetando negativamente o comércio entre as nações. Além disso, após o período da guerra, trau- 
mas ainda mais profundos foram sentidos em termos globais. Nesse sentido, com o fim da guerra, procurou-se

[...] montar um sistema que evitasse a possibilidade de mais um conflito em escala mundial, evitasse as crises de liquidez de divisas e impedisse os danos provocados pela imposição de barreiras comerciais (BAUMANN et al., 2004, p. 133).

Vale notar que iniciativas relativas ao reordenamento da economia mundial no pós-guerra tomaram lugar mesmo antes do fim do conflito. Em agosto de 1941, o presidente dos EUA, Roosevelt, e o primeiro-ministro britânico, Winston Churchill, assinaram a Carta do Atlântico (Atlantic Charter), "documento fundador" dos princípios que viriam a nortear a reconstrução da ordem internacional na segunda metade do século XX, e ao qual o Brasil aderiria no início de 1943. Sobre as características, motivações e importância da Atlantic Charter, Sato (2001, p. 5) relata:

O documento não era nem um acordo contratual e nem uma aliança com dispositivos formais. Era, antes, uma declaração de princípios que condenava a tirania sob todas as formas e enfatizava a necessidade do empenho pela construção de uma paz baseada na defesa da liberdade, no respeito às linhas de fronteira consolidadas, na autodeterminação das nações e na renúncia ao uso da força. O documento também entendia que esses princípios estavam inexoravelmente ligados a ações a serem empreendidas no plano econômico e recomendava que um esforço de cooperação entre as nações para se construir uma paz mais duradoura deveria contemplar a igualdade no acesso ao comércio e às matérias-primas e o desenvolvimento de formas mais estáveis de arranjo institucional necessárias à promoção da prosperidade e da segurança social para todos os povos. Obviamen- 
A Ordem Econômico-Comercial Internacional: Uma Análise da Evolução do Sistema...

te, a Carta do Atlântico teve por motivação fundamental articular o esforço de guerra das nações que lutavam contra o Eixo e seu teor não deixava dúvidas quanto à disposição e inevitabilidade do envolvimento direto dos Estados Unidos na guerra. Todavia, o documento foi, inegavelmente, peça importante na construção da ordem internacional do pós-guerra ao servir de base para dar início às consultas e negociações que iriam resultar nos Acordos de Bretton Woods e na assinatura da Carta das Nações Unidas.

A estruturação da nova ordem econômica internacional foi tomando forma a partir, fundamentalmente, da Conferência de Bretton Woods, realizada entre junho e agosto de 1944, ou seja, antes mesmo do fim efetivo da guerra. Ademais, as bases políticas para o estabelecimento de uma nova "confraria entre as nações" foram lançadas em Dumbarton Oaks, em agosto de 1944, tendo resultado na criação da Organização das Nações Unidas (ONU) em abril de 1945, por meio da Carta de São Francisco. Por fim, em Ialta, em fevereiro de 1945, e em Potsdam, entre julho e agosto do mesmo ano, foram esboçadas as linhas do contorno geopolítico que passaria a dividir o mundo de forma mais clara a partir de 1947.

O chamado Sistema de Bretton Woods construiu os pilares para o restabelecimento da ordem no campo monetário e financeiro internacional. Embora tanto nos EUA quanto na Grã-Bretanha existisse certo "consenso" acerca da fundação de uma ordem liberal que viesse a se contrapor às idéias e práticas protecionistas dos anos 1930, observou-se nessa Conferência a contradição entre as percepções norte-americanas e aquelas defendidas pelos britânicos. Tal fato ficou mundialmente conhecido a partir dos debates entre o representante dos EUA, Harry Dexter White, e o enviado britânico, John Maynard Keynes. A proposta norte-americana para o ordenamento das relações monetárias e financeiras internacionais predominou, 
tendo por base uma simples e poderosa idéia: "quem pagava as contas?”. Criou-se, então, o Fundo Monetário Internacional (FMI), enquanto provedor de liquidez internacional e atenuador de crises das contas externas dos países associados; e o Banco Internacional para a Reconstrução e o Desenvolvimento (BIRD), que, como o próprio nome já indica, foi encarregado de financiar a reconstrução e o desenvolvimento econômico dos países do mundo, principalmente das economias européias destruídas durante a Segunda Guerra Mundial. Por outro lado, ainda que na Conferência de Bretton Woods tenha sido ratificada a necessidade da construção de um sistema multilateral de livre-comércio para a estruturação do sistema econômico mundial no pós-guerra, não houve condições de se tratar do assunto durante a Conferência. Assim, ficou acertado que uma reunião especial deveria ser convocada nos anos seguintes para tratar do tema, como de fato ocorreu.

A participação brasileira no reordenamento econômico foi tímida, como era de se esperar, dado o seu limitado poder naquele período, tanto no plano econômico quanto no político. Após uma rápida tentativa de independência econômica na década de 1930, quando se observou o ensaio de preservação de um arranjo de equilíbrio entre as potências predominantes da época, as relações econômicas internacionais do Brasil caracterizaram-se por uma intensa relação com os EUA, especialmente a partir do ataque japonês a Pearl Harbor (1941), quando as nações do Eixo declararam guerra aos EUA, acabando por apressar o envolvimento brasileiro no conflito, ao lado dos Aliados. Sobre a participação brasileira na estruturação do ordenamento mundial no pós-guerra, Paulo Roberto de Almeida (2004, p. 114) coloca:

Na segunda conferência interamericana de consulta, realizada no Rio de Janeiro em princípios de 1942, as nações americanas hipotecavam solidariedade ao país agredido. O Brasil faz mais do que isso: concebendo a aliança como uma 
A Ordem Econômico-Comercial Internacional: Uma Análise da Evolução do Sistema...

excelente oportunidade para resolver os problemas da industrialização pesada e do suprimento militar, o governo de Vargas se decide por um envolvimento direto no conflito militar, algo não exigido pelos estrategistas aliados. No terreno econômico a colaboração também passa a ser a regra. Em maio de 1944, Roosevelt estende ao Brasil o convite para participar, junto com 43 outras "nações unidas e associadas", da conferência que deveria discutir a reconstrução econômica do pós-guerra.

Um ponto bastante importante, por vezes esquecido, também ressaltado por Paulo Roberto de Almeida (2004), é o da presença da União das Repúblicas Socialistas Sociéticas (URSS) no debate acerca do ordenamento político-econômico mundial no pós-Segunda Guerra. $\mathrm{O}$ autor relata:

Em todo caso, a "planificação" da ordem econômica do pós-guerra também reservou um papel para a URSS, a despeito da pequena importância que esta tinha nos fluxos monetários e comerciais internacionais. Ao assim procederem, os Estados Unidos queriam evitar o desastroso erro de Versalhes que, ao excluir uma potência - no caso, a Alemanha de Weimar - do concerto mundial, havia gerado o clima de instabilidade e desconfiança responsável pelo ulterior acirramento dos conflitos no continente europeu. Os Estados Unidos se mostraram sensíveis aos interesses soviéticos, em parte porque previam um grande intercâmbio entre matérias-primas soviéticas e manufaturados norte-americanos, o que, depois, revelou-se ilusório. (ALMEIDA, 2004, p. 118).

Não obstante o esforço norte-americano para dar certo grau de influência à URSS no quadro institucional que vinha sendo criado, a mesma não ratificou os acordos de Bretton Woods até dezembro de 
1945, ficando, portanto, de fora das primeiras instituições econômicas multilaterais criadas no mundo no pós-guerra.

A liderança dos EUA foi essencial no processo de reconstrução mundial após o Grande Conflito. Tal liderança, além de necessária, era "natural". Em 1945, os EUA, de forma ainda mais significativa do que havia ocorrido ao final da Primeira Guerra Mundial, haviam emergido como o grande credor internacional. Não se tratava apenas de uma concentração relevante das reservas de ouro nos EUA, mas também de um fosso econômico que se abriu entre esse país e o resto do mundo. O Produto Nacional Bruto (PNB) dos EUA, em 1950, foi de US\$ 381 bilhões, enquanto o da Grã-Bretanha alcançava US\$ 126 bilhões, o da URSS, US\$ 71 bilhões, e o da França, US\$ 50 bilhões. Na realidade, no período em questão, o PNB dos EUA (US\$ 381 bilhões) era maior do que a soma dos PNBs da URSS, Grã-Bretanha, França, Alemanha Ocidental, Japão e Itália (US\$ 356 bilhões). ${ }^{1}$ Ademais, a dinâmica da política internacional acabou por desembocar na Guerra Fria, quando foram constituídos dois blocos representativos de modelos político-econômicos distintos e antagônicos, dando aos EUA uma liderança ainda mais solitária sobre as economias de mercado.

O papel desempenhado pelos EUA na cena internacional a partir de 1945 teve influência importante, tanto no plano das idéias e princípios que viriam a nortear o desenrolar da dinâmica da política internacional, quanto no das ações efetivas, tomadas com objetivos que variavam, dependendo do quadro geopolítico mundial e de pressões e interesses internos.

A estruturação da ordem liberal pretendida no imediato pós-guerra trazia consigo um ar otimista no que diz respeito às construções institucionais da época. Não foi diferente com a pretensão de se criar uma organização voltada para o comércio internacional. A proposta norte-americana de realizar uma reunião especial para negociações 
A Ordem Econômico-Comercial Internacional: Uma Análise da Evolução do Sistema...

acerca da criação de tal organização foi colocada em prática e, sob os auspícios da recém-criada ONU, aconteceu, em Londres (em outubro de 1946), a primeira reunião da Comissão preparatória para Conferência sobre Comércio e Emprego das Nações Unidas, na qual seriam estabelecidos os fundamentos constitutivos de uma Organização Internacional do Comércio (OIC).

Entre abril e novembro de 1947, ocorreu, em Genebra, a segunda reunião da Comissão preparatória para a Conferência de Havana. Nesse encontro, ainda em um ambiente de crença e expectativas positivas em relação à criação da OIC em um futuro próximo, 23 países (entre eles, três latino-americanos: Brasil, Chile e Cuba) assinaram o Acordo Geral sobre Tarifas e Comércio (GATT), destinado a ser incorporado à Carta constitutiva da OIC. Ocorreu, então, a primeira Rodada de negociações multilaterais para a redução de barreiras tarifárias. Ademais, foram definidos os princípios básicos do Sistema Multilateral de Comércio contemporâneo e acertada a adoção temporária do GATT, que entraria em vigor a partir de janeiro de 1948, até que a OIC fosse discutida e aprovada pelas partes contratantes. O GATT teria um secretariado - chamado oficialmente de Interim Commission for the International Trade Organization (ICITO), com vinculação, ainda que apenas formal, à ONU - atuando em Genebra no sentido de servir como fórum para negociações de acordos específicos, que almejassem a redução de tarifas alfandegárias e outras barreiras ao comércio internacional.

Durante as negociações da Conferência sobre Comércio e Emprego das Nações Unidas, que veio a acontecer entre novembro de 1947 e março de 1948 em Havana, mais de cinqüenta países acordaram acerca da Carta de Havana, documento oficial que criava a OIC enquanto instituição responsável pelo comércio internacional. Tendo a Carta sido aprovada pelos participantes da Conferência, a constituição efetiva da OIC ficou dependendo apenas da ratificação do documento pelos países signatários, segundo suas normas internas. 
Algo digno de nota sobre a Conferência de Havana diz respeito à visão que os países mais pobres tinham acerca das negociações e resultados da mesma. Em geral, acreditavam que o tom desenvolvimentista perceptível na Conferência (o próprio nome traz algo nesse sentido) pudesse fornecer instrumentos factíveis de auxílio àqueles países que esboçavam uma saída em direção ao "paraíso" do mundo desenvolvido, industrializado. Não obstante tal fato, alguns tons destoantes eram ouvidos entre as vozes "subdesenvolvidas". Vários países latino-americanos deram apoio, por exemplo, a propostas que colocavam a constituição de zonas de preferências comerciais como mecanismo legal dentro do documento final da Conferência. ${ }^{2}$

Voltando à Carta de Havana e à sua ratificação pelos países signatários, vale colocar que, como levantado por Paulo Roberto de Almeida (2004, p. 117),

[...] a Carta da OIC incluía tantas exceções, lacunas e ambigüidades deliberadas que mesmo seus partidários mostravam muito pouco entusiasmo por ela - apenas dois países chegaram a ratificá-la: a Austrália de forma condicional e a Libéria incondicionalmente.

No entanto, o relativo desânimo acima relatado veio sendo "construído" não apenas com base em eventuais problemas de origem da Carta, mas também a partir de dois aspectos importantes, complementares e inter-relacionados, que tomavam contornos distintos no final da década de 1940, comparativamente àqueles percebidos no período logo posterior à guerra, quais sejam: 1) a mudança no contexto geopolítico mundial - o inicial convívio pacífico e respeitoso entre a URSS e os EUA no imediato pós-guerra havia se tornado tenso alguns anos após; a Guerra Fria desabrochava; e 2) o Congresso norte-americano, autoridade maior da política comercial externa dos EUA, mostrava-se cada vez menos desejoso de abrir mão de determi- 
A Ordem Econômico-Comercial Internacional: Uma Análise da Evolução do Sistema...

nados controles sobre a política comercial e tarifária dos EUA, o que poderia vir a acontecer com a ocasional criação da OIC.

O "resumo da ópera" relativo à Carta de Havana, justamente na confluência das tendências acima abordadas, pode ser feito a partir da decisão do Congresso dos EUA de não ratificar a Carta. Na realidade, com o aumento dos focos de tensão internacional, os assuntos relativos à segurança internacional - políticas estratégicas como o próprio Plano Marshall - passaram a ter maior relevância no Congresso dos EUA, comparativamente a temas predominantemente econômicocomerciais, como a Carta da OIC, com interesses focados em uma temporalidade mais estendida.

A não-ratificação da Carta de Havana pelos EUA foi o decreto de morte da nascente OIC. A nação que liderava o mundo ocidental em sua reconstrução no pós-guerra achou por bem não levar adiante sua própria proposta de criação de uma verdadeira instituição para gerir o comércio entre as diversas nações do globo. Nesse contexto, o GATT, pensado inicialmente enquanto instrumento temporário e que não demandava ratificação congressual pelo fato ser um acordo executivo, entra em cena de forma permanente e irá servir como uma quase-instituição internacional, organizadora do SMC contemporâneo por mais de quatro décadas. Como abordado por Sato (2001, p. 5):

Pode-se dizer que o GATT foi, de um lado, a forma contratual possível dentro do quadro das dificuldades econômicas e limitações institucionais do pós-guerra e, de outro, o arranjo que melhor se adequava à economia política internacional que se configurou na esteira da Segunda Guerra Mundial.

Valls (1997, p. 3) afirma que o Acordo Geral

[...] emergiu de negociações que visavam remover barreiras ao comércio e não de negociações que tivessem por objetivo o estabelecimento de 
regras gerais de comportamento das relações comerciais entre os países.

Sendo assim, não obstante a existência de um tímido sistema de enforcement (panels) desde o Acordo de 1947, reformado parcialmente em 1952, o SMC, sob os auspícios do GATT, não tinha poder disciplinatório efetivo sobre as partes contratantes. Tal aspecto acabava por trazer algum grau de incerteza e arbitrariedade das potências, principalmente dos EUA, para as trocas internacionais. ${ }^{3}$

Alguns autores pertencentes a correntes mais críticas, como Arrighi (2003), consideram o sistema multilateral organizado sob a orientação do GATT como sendo "o principal instrumento de formação do mercado mundial sob a hegemonia norte-americana" (ARRIGHI, 2003, p. 72), deixando nas mãos dos Estados, fundamentalmente dos EUA, o controle sobre o ritmo e a direção do processo de liberalização comercial multilateral. Nesse ponto, a hegemonia dos EUA se distanciaria daquela da Grã-Bretanha do século XIX, tendo em vista que a última aplicava um regime de livre-comércio unilateral, enquanto os EUA fariam uso do livre-comércio ideologizado como estratégia de negociação intergovernamental, a fim de expandir as oportunidades de inserção mundial para empresas e produtos norteamericanos. Destarte, observou-se, no âmbito multilateral, um grau de liberalização muito mais amplo sob a hegemonia dos EUA do que sob a britânica.

Desconsiderando-se, no momento, a relevância, ou não, e a validade, ou não, dos argumentos mais críticos acerca da caracterização do SMC, fato é que os princípios norteadores do mesmo (não-discriminação e reciprocidade) têm suas origens mais próximas naqueles que permearam os acordos bilaterais de comércio realizados pelos EUA a partir da Lei dos Acordos Recíprocos de Comércio (LARC), de 1934. Tal lei teve por finalidade o estímulo às exportações por meio da quebra de barreiras comerciais - ajudando, assim, no combate à recessão iniciada em 1929 - e aos entraves protecionis- 
A Ordem Econômico-Comercial Internacional: Uma Análise da Evolução do Sistema...

tas levantados por leis como a Lei de Tarifas Smoot-Hawley, de 1930. Por intermédio da LARC, o Congresso permitiu ao Executivo norte-americano a realização de acordos comerciais em bases de reciprocidade que reduzissem as tarifas aduaneiras dos EUA até o limite de $50 \%$, relativamente àquelas vigentes no período. Ademais, tais acordos continham em si a idéia de não-discriminação, representada pela Cláusula da Nação Mais Favorecida (NMF), na qual as concessões feitas bilateralmente eram, de forma automática, estendidas aos demais parceiros comercias do país. ${ }^{4}$

No GATT, em seu artigo I, está a Cláusula da Nação Mais Favorecida (NMF), na qual a idéia da não-discriminação é ratificada, ficando também garantida a multilateralização do processo negociador. ${ }^{5} \mathrm{~A}$ Cláusula da Reciprocidade é vista como estímulo importante para as negociações, uma vez que os países tendem a não realizar movimentos unilaterais de liberalização comercial, mas sim a fazer uso de uma concepção mercantilista do comércio para a condução do processo negociador da abertura comercial. Além disso, a proibição de restrições quantitativas e o princípio do tratamento nacional, no qual os produtos importados devem ter o mesmo tratamento que seus similares nacionais, apresentam-se como princípios complementares de suporte do SMC.

Desde o início, com o processo de entrada do Benelux e, posteriormente, quando da criação da Comunidade Européia em 1957, o princípio da NMF foi “desrespeitado". Porém, tais acontecimentos ocorreram dentro da legalidade presente na cláusula de escape do artigo XXIV, que trata da criação de zonas de livre-comércio e uniões aduaneiras, como já apresentado no presente trabalho. Assim, práticas que iam de encontro aos pilares fundamentais gattianos se tornaram aceitáveis segundo parâmetros específicos. No artigo XII, por exemplo, os países podem fazer uso de medidas temporárias que restrinjam as importações, quando houver problemas em seus Balanços de Pagamentos. No artigo XVIII, condicionado à aprovação pelas de- 
mais partes contratantes, admite-se o uso de instrumentos de assistência governamental para promover o desenvolvimento econômico, como no caso de apoio às indústrias nascentes de países em desenvolvimento. Já no artigo XIX (Cláusula de Salvaguarda), restrições ao comércio podem ser impostas, segundo regulamento, caso as concessões negociadas no GATT impliquem aumentos inesperados e danosos à indústria nacional. ${ }^{6}$

Observamos, pois, que as condições de excepcionalidade na aplicação dos princípios fundadores do GATT foram criadas no sentido de adaptar as normas à realidade das condições econômicas e políticas. Esse aspecto, como bem apresentado por Seitenfus (2005, p. 212), advém do duplo caráter do Acordo Geral enquanto organização responsável pelo trato do comércio entre as nações:

O GATT deve ser considerado como sendo uma organização internacional especial na medida em que possui duas faces distintas: por um lado, trata-se de um rol de normas procedimentais sobre as relações comerciais entre os EstadosPartes. Estas atividades são de cunho jurídico, pois dizem respeito à elaboração, prática e controle de regras de direito material. Por outro, trata-se de um fórum de negociação comercial onde, através de instrumentos próprios à diplomacia parlamentar, de natureza comercial, procura-se aproximar posições entre os EstadosPartes. Essa face é de natureza essencialmente política.

Como apresentado, a seguir, no Quadro 1, após a primeira Rodada de negociações em Genebra, em 1947, na qual foram negociadas 45 mil concessões tarifárias, sobre um valor total de comércio de US\$10 bilhões, ocorreu na cidade francesa de Annecy, em 1949, a segunda Rodada de negociações do GATT. Nesta última, apenas treze países participaram e 5 mil concessões tarifárias foram intercambiadas. Entre setembro de 1950 e abril de 1951, 38 países estiveram presen- 
A Ordem Econômico-Comercial Internacional: Uma Análise da Evolução do Sistema...

tes na Rodada Torquay, na qual a "morte" da OIC foi confirmada, e 8.700 concessões tarifárias foram negociadas, sendo os direitos aduaneiros reduzidos em 25\% de seu nível nominal de 1948, em média. A quarta Rodada de negociações comerciais multilaterais ocorreu em Genebra, em 1956, envolvendo dessa vez 26 países, que fizeram concessões tarifárias sobre um valor de comércio de US\$2,5 bilhões. ${ }^{7}$ Nessa última Rodada, também foi realizada uma "reforma" do SMC, necessária em virtude da não-implementação da OIC, criando um protocolo de emenda ao preâmbulo e às partes II e III do GATT.

\section{Quadro 1}

As Rodadas de Negociações Comerciais do GATT

\begin{tabular}{|c|c|c|c|}
\hline Ano & Local/(Nome) & Assuntos Cobertos & Países \\
\hline 1947 & Genebra & Tarifas & 23 \\
\hline 1949 & Annecy & Tarifas & 13 \\
\hline 1951 & Torquay & Tarifas & 38 \\
\hline 1956 & Genebra & Tarifas & 26 \\
\hline $1960-1961$ & Genebra / (Rodada Dillon) & Tarifas & 26 \\
\hline $1964-1967$ & Genebra / (Rodada Kennedy) & Tarifas e medidas antidumping & 62 \\
\hline $1973-1979$ & Genebra / (Rodada Tóquio) & $\begin{array}{c}\text { Tarifas, medidas não tarifárias } \\
\text { e acordos jurídicos. }\end{array}$ & 102 \\
\hline $1986-1994$ & Genebra / (Rodada Uruguai) & $\begin{array}{c}\text { Tarifas, medidas não tarifárias, } \\
\text { normas, serviços, propriedade } \\
\text { intelectual, têxteis, agricultura, } \\
\text { solução de controvérsias, } \\
\text { criação da OMC etc. }\end{array}$ & 123 \\
\hline
\end{tabular}

Fonte: OMC (2005a).

A Rodada Dillon (nome do secretário do Comércio dos EUA de então) teve como principais motivações, segundo Rêgo (1996, p. 7), a criação da Comunidade Econômica Européia (CEE), pelo Tratado de Roma de 1957, e os impactos de sua política comercial comum sobre as demais partes contratantes do GATT. Com 26 países envolvidos, 4.400 concessões tarifárias foram intercambiadas, representando um montante de US $\$ 4,9$ bilhões. Vale aqui notar que as negocia- 
ções no GATT tinham foco primordial, e quase que exclusivo, na redução de barreiras tarifárias para produtos industrializados. Tal fato será observado até a Rodada Uruguai, quando novos (e antigos, mas pendentes) temas, como produtos agrícolas, têxteis e serviços, serão inseridos na agenda negociadora. Outro ponto digno de nota diz respeito ao descontentamento com o insucesso relativo do método bilateralista de negociações no GATT, o qual, por causa do aumento progressivo da complexidade do sistema, acabou por reduzir o ritmo do processo de liberalização tarifária, em comparação com aquele observado na primeira Rodada em Genebra.

Bueno (1994), analisando o papel desempenhado pela diplomacia brasileira no SMC ao longo de sua evolução, coloca que as negociações no GATT parecem não ter tido prioridade na agenda do Itamaraty. Não obstante a existência de certa retórica multilateralista nas posições da política exterior do Brasil, e sua participação na criação do SMC contemporâneo, grande parte do comércio exterior brasileiro da época era regido por acordos bilaterais. Para Bueno (1994, p. 75), o comparecimento da delegação brasileira nas rodadas de Annecy, Torquay e Genebra sem instruções específicas, improvisando e, muitas vezes, referindo-se em seus posicionamentos a assuntos já tratados, denota o grau de relativo desprezo dado pela diplomacia brasileira ao SMC, naquele momento. Baumann et al. (2004, p. 176) dizem que: "As razões para a adesão do país ao GATT desde o início estariam aparentemente relacionadas à percepção de evitar o pagamento de um custo futuro maior em termos de abertura comercial".

Após uma ampla reforma tarifária feita em 1957, o Brasil realizou pedidos de derrogações tarifárias no GATT, e foi compelido a revisar suas condições de acesso (na verdade uma nova adesão) ao SMC. Tal revisão veio a acontecer por meio de uma longa e difícil renegociação das concessões sobre direitos aduaneiros com todos os demais países que faziam parte do Acordo Geral. Como explicitado por Paulo Roberto de Almeida (2004, p. 120): 
A Ordem Econômico-Comercial Internacional: Uma Análise da Evolução do Sistema...

Na ocasião, sendo o Brasil um dos poucos países em desenvolvimento aderentes ao GATT e se ressentindo dos duros efeitos de um contrato entre "iguais" para parceiros desiguais, setores econômicos internos chegaram inclusive a questionar a utilidade, em termos práticos de comércio exterior, de uma adesão estrita do País aos princípios do GATT. Essa contestação implicaria, entretanto, para o Brasil, uma denúncia formal do Acordo e uma saída do sistema de concessões recíprocas do GATT, o que foi julgado excessivo na época.

Cabe aqui ressaltar que, em meados da década de 1950, a partir de queixas por parte dos países em desenvolvimento de que seus interesses não estariam sendo levados em conta no SMC, as partes contratantes do GATT estabeleceram um comitê de especialistas para realizar um estudo sobre o caso. Fizeram parte do comitê, além do professor Haberler, que o presidia (daí o comitê ter ficado conhecido como The Haberler Commitee), Meade, Tinbergen e Roberto Campos. O Haberler Commitee Report, de 1958, deixou claro que o problema do fraco dinamismo das exportações dos países em desenvolvimento estava ligado às políticas comerciais utilizadas pelos países mais avançados, impondo barreiras excessivas àqueles produtos em que os países menos desenvolvidos teriam potencial de ganho mais significativo, via comércio internacional.

Em meados da década de 1950, mesmo com algumas reformas que buscavam dar maior legitimidade ao sistema, o GATT continuava a atender de forma importante, na visão dos países em desenvolvimento (inclusive do Brasil), aos interesses e necessidades dos países desenvolvidos. Era visto, pois, pelos países pobres, como um rich men's club.

Ademais, a queda gradual da participação dos países em desenvolvimento no comércio internacional, nas décadas de 1950 e 1960, junta- 
mente com os trabalhos seminais de Raúl Prebisch acerca do intercâmbio desigual entre os países, reforçavam a idéia de que os países em desenvolvimento vinham sendo prejudicados pela configuração das relações econômicas de então. Prebisch nota, a partir de análises empíricas, que havia uma tendência à deterioração dos termos de intercâmbio das economias periféricas em suas relações com os centros econômicos. Tal acontecimento estaria ligado à diferença entre a elasticidade-renda dos produtos primários exportados pelos países em desenvolvimento e aquela de suas importações. Além disso, a relativa inelasticidade-preço da oferta dos produtos primários aumentava as pressões geradoras de desequilíbrios externos nos países da periferia, dificultando ainda mais seu processo de desenvolvimento econômico. Como colocado por Paulo Roberto de Almeida (1999, p. 103): "Essa conceitualização rompia com os padrões normalmente aceitos nas relações econômicas internacionais".

Na Rodada Dillon, o Brasil entrou com representação contrária à formação da CEE e a seus acordos preferenciais de comércio com áreas coloniais de países europeus, com base nos prejuízos sofridos pela exportação brasileira de café e cacau para o mercado europeu. A diplomacia brasileira colocava, então, que a integração econômico-comercial européia não poderia ser feita em detrimento de nações como o Brasil, que seriam abaladas por uma zona preferencial de comércio, a qual, ademais, desviaria artificialmente correntes de investimentos. Vale notar que se vivia, no período, o auge do nacional-desenvolvimentismo no governo Juscelino Kubitschek (JK), no qual era clara a idéia de que a política externa do país deveria ser empregada como importante ferramenta do governo para promover o desenvolvimento nacional. Destarte, por meio da ação diplomática, o governo empenhou-se no exterior para obter o suporte indispensável à industrialização.

Toda essa conjuntura de insatisfação e repulsa à ordem econômico-comercial estabelecida resultou, em 1964, na primeira Conferên- 
A Ordem Econômico-Comercial Internacional: Uma Análise da Evolução do Sistema...

cia das Nações Unidas sobre Comércio e Desenvolvimento (em inglês, United Nations Conference on Trade and Development (UNCTAD)). A UNCTAD servirá como base para os países em desenvolvimento em sua tentativa de pressionar por reformas importantes do SMC e pelo estabelecimento de um sistema de preferências, não recíproco, beneficiando-os. É válido observar que a diplomacia brasileira teve importância capital durante toda a fase de preparação e constituição da UNCTAD, dando uma contundente colaboração para o surgimento de uma organização que, pela primeira vez na história econômica mundial, tinha seu foco de ação verdadeiramente voltado para o problema do desenvolvimento. ${ }^{8}$

Como primeiro resultado das pressões unctadianas, em 1965, durante a Rodada Kennedy, inseriu-se a parte IV no GATT. Nessa nova parte do Acordo Geral ficou reconhecida a necessidade de se prover “condições mais favoráveis e aceitáveis" às exportações de produtos primários dos países em desenvolvimento, além de acesso ampliado, sob condições favorecidas, aos produtos processados e manufaturados pelos países de menor desenvolvimento econômico. Vale ressaltar que, inicialmente, a parte IV indicava a possibilidade do tratamento não recíproco, permanecendo, assim, como uma declaração de princípios. Tal caráter malformado da não-reciprocidade só será efetivamente revisado e incorporado ao GATT na Rodada Tóquio, pela Cláusula de Habilitação.

Na Rodada Kennedy, que durou de 1964 a 1967, observou-se a continuação do aprofundamento das concessões tarifárias sobre produtos industrializados, com participação crescente de países. Mais de sessenta países participaram da sexta Rodada de negociação do GATT, na qual se acordou uma redução de até 50\% (tendo sido 35\% efetivados) nas tarifas aduaneiras aplicadas sobre produtos industrializados, correspondendo a um volume de comércio de cerca de US\$ 40 bilhões. Ademais, iniciou-se a discussão sobre o problema do dumping, empurrada principalmente por interesses dos países de- 
senvolvidos, e que resultou no primeiro código antidumping do GATT. Cabe aqui ressaltar que, a partir da Rodada Kennedy, o método de negociação foi mudado para atender à complexidade crescente do sistema, e talvez a alguns interesses específicos, passando a redução linear de tarifas a ser efetivada como resultado.

\section{Quadro 2}

Tarifa Média Mundial, 1947-2000

\begin{tabular}{|c|c|c|}
\hline Ano & Período & Tarifa média \\
\hline 1947 & Estabelecimento do GATT & $38 \%$ \\
\hline 1962 & Pré-Rodada Kennedy & $17 \%$ \\
\hline 1972 & Pós-Rodada Kennedy & $9 \%$ \\
\hline 1987 & Pós-Rodada Tóquio & $6 \%$ \\
\hline 2000 & Pós-Rodada Uruguai & $4 \%$ \\
\hline
\end{tabular}

Fonte: OMC (2005a).

Analisando o Quadro 2, podemos observar que, não obstante os percalços e insatisfações do caminho, o SMC, sob os auspícios do GATT, teve sucesso em seu objetivo de redução tarifária pela via multilateral negociada. Em 1947, quando da primeira Rodada de negociações multilaterais em Genebra (onde o próprio GATT foi criado), a tarifa média mundial era de 38\%. A importância da Rodada Kennedy de negociações, no que respeita ao processo de queda das tarifas aduaneiras sobre o comércio de bens (fundamentalmente manufaturados), pode ser observada pela redução da tarifa mundial média de $17 \%$, no período anterior ao lançamento da Rodada, para 9\%, alguns anos após a mesma. Sabe-se que a tarifa média mundial é muito agregada para se ter uma idéia mais particular sobre o processo de liberalização em setores econômicos; contudo, esse processo nos apresenta, mesmo que genericamente, a tendência observada com respeito ao nível de liberalização mundial dos fluxos de comércio.

Desse modo, durante a Rodada Kennedy, o SMC passou por mudanças significativas, que deram início a uma nova etapa. Tais transfor- 
A Ordem Econômico-Comercial Internacional: Uma Análise da Evolução do Sistema...

mações estão fundamentadas tanto na organização dos países em desenvolvimento na UNCTAD, dando aos mesmos um papel mais ativo na construção da ordem econômico-comercial de então, quanto no começo de outras modificações internas, que incluem a ampliação progressiva dos temas relacionados ao comércio internacional tratados pelo GATT, como antidumping e comércio de produtos agrícolas, que viriam a ser negociados paulatinamente em rodadas posteriores.

\section{A Rodada Tóquío e a Rodada Uruguai}

\section{O neoprotecionismo e as novas estratégias negociadoras dos Estados Unidos}

A década de 1970 foi marcada por mudanças substanciais na ordem econômica internacional. O Sistema de Bretton Woods, construído no imediato pós-guerra, apresentava fragilidades que acarretaram o seu fim, ou pelo menos transformações importantes na forma de gerência global das relações monetárias e financeiras entre as nações. $\mathrm{O}$ fim do padrão dólar-ouro, em 1971, e o conseqüente fim do câmbio fixo, em 1973, acabaram por trazer à tona novos desafios ao sistema internacional, tendo em vista que a configuração monetária que deu ao capitalismo mundial condições relativamente estáveis de crescimento, entre as décadas de 1950 e 1970, não mais existia.

Somavam-se aos problemas de ordem econômico-monetária aqueles ligados ao aumento dos preços do petróleo em 1973, em virtude do choque de oferta da Organização dos Países Exportadores de Petróleo (OPEP) e de suas consequiências sobre o ritmo do crescimento econômico mundial, bastante petróleo-intensivo, além da geração de mudanças na configuração do mercado financeiro internacional, cada vez mais inundado por petrodólares. Em 1979, com a Revolu- 
ção Iraniana, mais uma vez o ouro ne gro viria a ter seu preço no mercado internacional aumentado significativamente, o que acabaria por gerar um quadro recessivo para a economia mundial, com evidentes efeitos sobre o comércio internacional.

Ademais, algumas tendências quanto à distribuição do poder econômico no mundo, iniciadas nas décadas anteriores, viriam a tomar forma mais clara a partir dos anos 1970, modificando substancialmente o cenário econômico internacional. A ascensão da economia japonesa e da Europa Ocidental trariam consigo o início da contestação à hegemonia dos EUA nos campos econômico e tecnológico, transformando assim as atitudes e estratégias da política externa norte-americana, tanto no plano bilateral quanto em negociações multilaterais do GATT. No que concerne a este último, a nova configuração de forças e interesses econômicos no mundo, gerando conseqüentes transformações no campo comercial, exigia uma atualização do SMC para atender a essa nova realidade, que se apresentava cada vez mais complexa e ambígua.

Em virtude de tais desdobramentos históricos da economia mundial, a relação entre os EUA e o mundo desenvolvido se modificou. A perda de competitividade internacional de setores importantes da economia norte-americana, principalmente em indústrias de alta tecnologia, e o aumento paulatino dos deficits comerciais dos EUA, a partir de meados da década de 1970, fizeram com que esse país deixasse de lado posicionamentos mais permissivos em relação tanto ao Japão quanto à Europa Ocidental. Além disso, tornou-se freqüente o uso de novos mecanismos de proteção comercial destinados àquelas indústrias nacionais com menor competitividade internacional. Tais mecanismos eram fundamentados em barreiras não tarifárias que visavam à redução quantitativa de importações, tais como restrições voluntárias de exportações, antidumping, direitos compensatórios, salvaguardas etc. 
A Ordem Econômico-Comercial Internacional: Uma Análise da Evolução do Sistema...

Aflorado esse contexto de neoprotecionismo, os EUA passarão a adotar novas estratégias de negociação no GATT, podendo-se observar tal fato de forma mais visível a partir da Rodada Tóquio. Antes, porém, de nos atermos especificamente às novidades da política comercial externa dos norte-americanos no SMC, a partir da década de 1970, cabe aqui apresentarmos alguns comentários auxiliares sobre a conjuntura comercial internacional e também sobre a política de comércio exterior dos EUA.

Como relatado por Ricupero (2002), a teoria da estabilidade hegemônica, paradigma conceitual dominante nas análises acerca da economia política das relações internacionais, coloca que "a abertura da economia global depende criticamente da presença de um país hegemônico que possui tanto os motivos quanto os meios para estabelecer uma ordem comercial liberal" (RICUPERO, 2002, p. 9). Dessa forma, alguns estudiosos afirmam que a perda relativa da hegemonia econômica norte-americana teria feito com que a ordem comercial liberal do pós-guerra desabasse, estando a prova para tal fato no crescente uso de medidas protecionistas por parte dos EUA a partir dos anos 1970.

Embora possamos considerar correta a idéia de que a perda relativa da hegemonia da economia dos EUA foi importante fator de fomento a práticas protecionistas, cabe lembrar que a política de comércio exterior de um país não é construída exclusivamente a partir de sua posição no cenário internacional. Os condicionamentos e interesses domésticos são substancialmente relevantes quando se analisa a posição de uma nação em referência à sua política de comércio exterior, principalmente no caso dos EUA.

O Congresso dos EUA tem a supremacia sobre a política de comércio exterior do país. ${ }^{9}$ Como apresenta Godinho (2005, p. 19-20):

Não há um "comandante-em-chefe do comércio" previsto na Constituição. A clareza com 
que ela atribui a função de regulamentar o comércio exterior ao Congresso dá a este a primazia neste campo. Qualquer iniciativa presidencial só pode concretizar-se com o expresso consentimento do Poder Legislativo; $;^{10}$ e, além disso, este pode tomar a iniciativa.

Diante de tal configuração de poder e responsabilidades, podemos observar que no Congresso dos EUA os interesses de grupos econômicos de pressão estão representados, sendo portanto a influência, ou não, de tais grupos no Capitólio um ponto determinante na construção das posições comerciais dos EUA relativamente aos seus parceiros, nos mais diversos setores econômicos. Vale ressaltar que a descentralização das decisões de política comercial nos EUA foi de grande valia para a proteção da economia, desde as políticas de defesa das indústrias nascentes até a atualidade, quando alguns setores, como o agrícola, continuam a ter subsídios e proteção tarifária e não tarifária como barreiras efetivas, que lhes permitem a sobrevivência.

A história da legislação comercial dos EUA deixa clara a crescente influência dos grupos de interesse na definição da política comercial do país, desde a Lei de Expansão do Comércio de 1962, passando pela Lei de Comércio de 1974 e pela Lei de Comércio e Tarifa de 1984, até a Lei Omnibus de Comércio e Competitividade, de 1988. Com o passar do tempo, as demandas protecionistas tornam-se mais sofisticadas no sentido de que buscam, por meio de novos mecanismos, a criação de instrumentos efetivos para responder às supostas práticas desleais dos parceiros comerciais dos EUA. É justamente nesse processo de mudança das posições protecionistas que veremos os norte-americanos iniciarem o uso de novas estratégias negociadoras.

Dias (1996) apresenta, de forma sucinta, esse novo comportamento da potência econômica do mundo capitalista relativamente às negociações comerciais, indicando a mudança em dois importantes conceitos negociadores. A autora coloca que: 
A Ordem Econômico-Comercial Internacional: Uma Análise da Evolução do Sistema...

A partir da Rodada Tóquio (1973-1979), os Estados Unidos começaram a utilizar dois novos conceitos negociadores, cujo significado foi explicitado ao longo dos últimos anos, tornando-se, com o tempo, mais evidente a sua contradição com o contexto de liberalização do comércio. Primeiro, a noção de livre comércio foi substituída pela de comércio "eqüitativo" (fair trade), e a noção de reciprocidade efetiva no acesso a mercados, em termos de resultados, substituiu a reciprocidade anterior, associada à igualdade de oportunidades. (DIAS, 1996, p. 61).

Esses novos conceitos se afastam de vez da idéia de liberalismo administrado, qualificação do marco institucional do comércio internacional, vislumbrado no GATT pela Cláusula da NMF e da reciprocidade anterior, aproximando-se assim da idéia de comércio administrado, conceito ligado a uma visão em que os governos atuam no âmbito internacional no sentido de dividir mercados entre suas empresas, de forma mutuamente satisfatória.

Tais mudanças de posicionamento dos EUA trouxeram consigo um potencial de conflito de interesses mais significativo dentro do GATT. Como aborda Abreu (1998, p. 6):

Na Rodada Tóquio (1973-1979) pela primeira vez houve um conflito evidente entre os mais adiantados países em desenvolvimento, como o Brasil, e os Estados Unidos, na busca de reciprocidade em termos de concessões concretas.

Assim, o cenário internacional no qual a Rodada Tóquio acontece é bastante distinto daqueles nos quais as rodadas anteriores foram negociadas. Além das modificações estruturais ocorridas no mundo desenvolvido, que acabaram, em conjunto com outros fatores, por levar os EUA a realizar mudanças importantes em sua estratégia de política comercial, os anos 1970 assistiram ao ponto alto da tendência re- 
formadora da agenda econômica internacional, por parte dos países em desenvolvimento.

Esse novo contexto participativo dos países da periferia do sistema internacional pôde ser vislumbrado na aprovação sucessiva, nas assembléias da ONU ou de seus órgãos subsidiários (Conselho Econômico e Social das Nações Unidas (em inglês, Economic and Social Council (Ecosoc)) e UNCTAD), de resoluções ou declarações sobre a Nova Ordem Econômica Internacional, ordem essa que teria como objetivo primordial dar mais vez e voz aos países em desenvolvimento, trazendo a questão do desenvolvimento econômico e da eqüidade do poder mundial para o centro das discussões. ${ }^{11}$ Os países em desenvolvimento continuavam, pois, sua ofensiva pelo estabelecimento de regras diferenciais e tratamento mais favorável, ao passo que os países desenvolvidos eram convidados a estender cada vez mais concessões unilaterais e sem caráter de reciprocidade em benefício dos primeiros.

O Sistema Generalizado de Preferências (SGP), criado na II UNCTAD, em 1968, que traduzia a derrogação, na prática, do princípio da reciprocidade do SMC, foi autorizado pelo GATT em 1971. Os países em desenvolvimento tentaram, na Rodada Tóquio, institucionalizar de forma permanente o SGP no GATT.

Por intermédio da Enabling Clause (Cláusula de Habilitação), adotada ao fim da Rodada Tóquio, o princípio da não-reciprocidade toma forma explícita e efetiva. Desse modo, a declaração de princípios relativa à parte IV do Acordo Geral, introduzida na Rodada Kennedy, passa a fazer parte do quadro legal do GATT como um mecanismo de tratamento especial aos países em desenvolvimento. A Cláusula de Habilitação deixa claro que:

Os países desenvolvidos não esperam que os países em desenvolvimento aportem, no curso das negociações comerciais, contribuições in- 
A Ordem Econômico-Comercial Internacional: Uma Análise da Evolução do Sistema...

compatíveis com as necessidades de desenvolvimento, das finanças ou do comércio de cada um dos países. As partes contratantes desenvolvidas não procurarão alcançar, e as partes contratantes menos desenvolvidas não serão obrigadas a acordar, concessões incompatíveis com as necessidades de desenvolvimento, de finanças e de comércio destas últimas. (CLÁUSULA DE HABILITAÇÃO, parágrafo 5 apud ALMEIDA, 2004, p. 123).

Embora os países em desenvolvimento tenham trabalhado com empenho para a instituição do SGP em bases permanentes, suas demandas não foram atendidas. O SGP foi, sim, aprovado, porém em base temporária, sujeito à graduação. Sobre esse aspecto, Paulo Roberto de Almeida (2004, p. 119) coloca que no SMC:

Na prática, aceita-se uma série de derrogações ao princípio da NMF, sem que isso se traduza na letra da lei, esperando os países desenvolvidos um "retorno gradual" das partes menos desenvolvidas ao sistema jurídico consolidado (graduação), isto é, a aplicação da igualdade de direitos e obrigações que está na base do Acordo Geral de 1947.

Mais de cem países participaram das negociações da Rodada Tóquio, que levaram a uma redução da tarifa média sobre produtos manufaturados em cerca de $30 \%$, representando um comércio global de US\$ 300 bilhões. ${ }^{12}$ Ademais, houve a elaboração de códigos reguladores com respeito a algumas barreiras não tarifárias, como compras governamentais, subsídios e direitos compensatórios, antidumping, valoração aduaneira etc. Tais códigos eram assinados somente por aqueles países que tivessem interesse em fechar acordos em áreas específicas cobertas pelos códigos, sendo, pois, de participação voluntária, o que os colocava fora da estrutura formal do GATT. Um ponto interessante a ser abordado é que cada um desses códigos trazia con- 
sigo regras para a resolução de controvérsias relativas aos temas de que tratavam. Assim, a resolução dessas disputas poderia não estar entre as atribuições do sistema de controvérsias do GATT, sistema esse que foi revisado, com a aprovação de novas regras de solução, na Rodada Tóquio, mas permaneciam sem um aparato de enforcement poderoso e eficaz.

Provavelmente o fruto mais importante gerado na Rodada foi a reforma do GATT, com a incorporação efetiva de um tratamento diferencial e mais favorável para países em desenvolvimento, por meio da Enabling Clause (Cláusula de Habilitação). Entretanto, mesmo com a criação do tratamento diferenciado, os "países periféricos" não viram suas demandas totalmente atendidas, tendo em vista que não se conseguiu chegar a um resultado nas negociações na área agrícola e também na questão de salvaguardas durante a Rodada. Ademais, os países desenvolvidos ficaram frustrados com o pequeno número de países em desenvolvimento que subscreveram os códigos.

Os resultados efetivos da Rodada Tóquio em relação às barreiras não tarifárias foram pouco significativos. Segundo Rêgo (1996), o sucesso apenas relativo de tais negociações em relação a questões não tarifárias se deveu a dois fatores, quais sejam: "o sucesso das negociações quanto à redução das tarifas para níveis baixos e as recessões econômicas dos anos 70 e início dos anos 80 (desencadeadas, em parte, pelos dois choques de petróleo)" (RÊGO, 1996, p. 8). Tais fatores fomentaram a criação, nos países desenvolvidos, como já foi aqui abordado, de novas formas de proteção para os setores mais significativamente prejudicados pela competição internacional.

Ao final da Rodada Tóquio, os descontentamentos, tanto dos países em desenvolvimento quanto daqueles desenvolvidos, foram inseridos em um programa de trabalho que viria a ser lançado na reunião ministerial do GATT, em Genebra, em 1982. Já nessa reunião ministerial os EUA tentaram o lançamento de uma nova Rodada de negoci- 
A Ordem Econômico-Comercial Internacional: Uma Análise da Evolução do Sistema...

ações multilaterais que englobasse novos temas ligados à harmonização de políticas públicas em âmbito global. Contudo, a resistência dos países em desenvolvimento, com o apoio da Comunidade Européia, falou mais alto naquele momento. $\mathrm{Na}$ ocasião, a diplomacia econômica brasileira desempenhou papel importante enquanto liderança dos países em desenvolvimento, conjuntamente com a Índia, opondo-se firmemente à inclusão de novos temas, como serviços, na agenda negociadora do GATT. Os países em desenvolvimento viam como fundamental a resolução de questões pendentes em um primeiro momento, para depois pensar na inclusão de novas demandas e no lançamento de uma nova Rodada multilateral de negociações. Como coloca Feliciano de Sá Guimarães (2005, p. 105):

No início da década de 80 a posição do G5 (Brasil, Índia, Argentina, Iugoslávia e Egito) no GATT, antes de apoiar o lançamento de uma nova Rodada, era a de solucionar algumas lacunas dos acordos firmados na Rodada anterior. Os temas defendidos em 1982 eram: assegurar a implementação dos códigos da Rodada Tóquio antes do lançamento de uma nova; não iniciar outra Rodada sem antes resolver satisfatoriamente velhas questões (agricultura e têxteis); obter dos países desenvolvidos a garantia de que os mesmos não aumentariam as tarifas no curso da negociação (standstill); alcançar a abolição de todas as práticas comerciais que fossem contra as regras do GATT antes do lançamento da Rodada (rollback), e não discutir os novos temas enquanto os antigos não fossem resolvidos.

A importância dos novos temas para os EUA deriva de fatores atrelados tanto à ordem política internacional quanto às questões relacionadas a problemas econômicos internos. A apreciação do dólar durante a década de 1980 fez com que diversos setores da economia norte-americana ficassem expostos a maior concorrência com pro- 
dutos importados. Tal fato acabou por ter efeitos importantes nas contas externas dos EUA. O deficit comercial do país iniciou uma trajetória de rápida deterioração, chegando em 1987 a superar US\$ 150 bilhões, um recorde na época. Enquanto isso, o Japão e a Alemanha seguiam apresentando os maiores superavits comerciais do mundo.

No que diz respeito à política internacional, a Guerra Fria entrava no ocaso na década de 1980, com a URSS iniciando suas reformas, tanto no plano político quanto no econômico. Essa conjuntura permitiu aos EUA colocar seus interesses puramente econômicos acima daqueles relacionados à geopolítica, dando espaço para a grande potência capitalista usar, de forma mais aberta e tranqüila, o seu market power como elemento de pressão, de ameaça e de possíveis retaliações contra seus parceiros comerciais na busca de mercados para suas empresas.

É justamente a partir dos anos 1980 que os EUA irão, a exemplo do que já vinha fazendo a Comunidade Européia, iniciar a negociação de acordos bilaterais de comércio, como o primeiro acordo com Israel, em 1985. Por meio desses acordos, os EUA esperavam conseguir negociar de forma mais benéfica para seus interesses pontos controversos que, em uma negociação multilateral, seriam aprovados com maior dificuldade. O jogo comercial bilateral, tête-à-tête, colocava a maior potência econômica do mundo em clara vantagem negociadora. $^{13}$

As mudanças na estratégia dos EUA perante o GATT, juntamente com a crescente bilateralização das negociações comerciais com seus parceiros, levam à criação de um ambiente paradoxal no SMC. Os países em desenvolvimento vêem-se na necessidade de defender o multilateralismo comercial, sem, contudo, possuírem poder político suficiente para dar legitimidade ao sistema. Com o Brasil não foi diferente. Ocorre, assim, uma mudança no posicionamento do Brasil 
A Ordem Econômico-Comercial Internacional: Uma Análise da Evolução do Sistema...

relativamente ao SMC. O país passa a atuar de forma mais efetiva na defesa do SMC e seus princípios legais, deixando de lado antigas posições defensivas em relação aos acordos multilaterais. A seguinte frase de Lacordaire resume bem a atuação da diplomacia brasileira na defesa do multilateralismo comercial: "Entre o forte e o fraco, entre o rico e o pobre, entre o mestre e o servo, é a liberdade que oprime e a lei que liberta". O Brasil tinha, pois, na defesa do SMC fundamentada no direito, a possibilidade de restrição do exercício do poder e da arbitrariedade pelas potências mundiais, especialmente pelos EUA.

Como apresentado anteriormente, quando se falou da teoria da estabilidade hegemônica, os EUA só tiveram capacidade de fazer o papel do hegemon na cena internacional nas primeiras décadas do pósguerra. A partir dos anos 1970 e, principalmente, nos anos 1980, os EUA passaram a apresentar estratégias de negociação nas quais buscavam de forma mercantilista mercados para seus produtos e proteção para suas indústrias menos competitivas. Nesse contexto, inicia-se no SMC uma verdadeira caça aos free riders (caroneiros). Os caroneiros eram, fundamentalmente, os países em desenvolvimento que participavam do SMC defensivamente, e tiravam proveito da liberalização multilateral acertada entre os países desenvolvidos. $\mathrm{Na}$ oitava Rodada de negociações do GATT, a caça aos free riders será definitiva, e os países em desenvolvimento terão de se comprometer com a abertura gradual de suas economias ao comércio internacional em diversos setores. ${ }^{14}$

Para Baumann et al. (2004), a postura de free rider do Brasil nas negociações comerciais acabou por gerar três conseqüências mais importantes, quais sejam: 1) ampliação do acesso aos principais mercados; 2) geração de crescente desconfiança por parte dos parceiros comerciais; e 3) enorme postergação da tomada de consciência, por parte dos agentes econômicos nacionais, da importância das negociações multilaterais (BAUMANN et al., 2004, p. 176). 
Esse complexo quadro de interesses, pressões e mudanças estratégicas entre os mais diversos países do mundo capitalista se fez presente nos trabalhos preparatórios ao lançamento de mais uma Rodada de negociações do GATT. Vale acrescentar que, na década de 1980, observamos uma crise do sistema financeiro internacional que acabou por assolar, primeiramente, o México, em 1982 e, posteriormente, outros países em desenvolvimento, entre eles o Brasil, em 1987. Os EUA fizeram uso dessa fragilidade e vulnerabilidade das economias em desenvolvimento para exercer pressões no sentido de levar adiante o lançamento de uma nova Rodada no GATT, na qual novos temas seriam inseridos. ${ }^{15}$

O consenso necessário para o lançamento de uma nova Rodada de negociações no GATT só foi alcançado na reunião ministerial de Punta del Este, no Uruguai, em setembro de $1986 .{ }^{16}$ Ficou acordado, então, que tanto temas pendentes (como agricultura, têxteis, subsídios) quanto novos temas (como serviços, propriedade intelectual, investimentos) seriam negociados. Contudo, as negociações de bens e serviços seriam realizadas de forma separada, atendendo a demandas do G-10 e de alguns outros países em desenvolvimento. Um fato importante que vem a acontecer na Rodada Uruguai é a idéia do single undertaking nas negociações do comércio de bens, na qual o país ou aceitaria todos os dispositivos negociados ou nada. Esse aspecto traz uma diferença substancial da Rodada Uruguai em relação às rodadas anteriores, tendo em vista que nelas era possível que um país aceitasse determinados acordos em certas áreas e refutasse outros que não lhe parecessem benéficos. ${ }^{17}$ Destarte, o mandato negociador da Rodada Uruguai comprometia-se a realizar a mais ampla e complexa negociação multilateral da história. A previsão inicial era a de que a Rodada duraria quatro anos, porém a complexidade das negociações fez com que os trabalhos da Rodada durassem praticamente o dobro. 
A Ordem Econômico-Comercial Internacional: Uma Análise da Evolução do Sistema...

Um importante fato, que viria a influir de forma significativa nos rumos da Rodada Uruguai, acontece em 1988 nos EUA. O presidente Reagan assina o Omnibus Trade and Competitiveness Act, que dá ao Executivo o poder de negociar a Rodada Uruguai sob os auspícios do fast-track e, ao mesmo tempo, reforça o uso da seção 301 . $^{18}$ Sobre esta última lei e as mudanças dela decorrentes, Godinho (2005, p. 24) traça comentários esclarecedores:

Esta lei reforçou os poderes do USTR [United States Trade Representative; em português, Representante Comercial dos Estados Unidos] ao transferir, do presidente para este órgão, o poder de aplicar sanções de retaliação aos países que incorressem em "práticas comerciais injustas". Ainda que a lei faculte ao presidente abolir as sanções por razões econômicas ou de segurança, o fato é que ela torna as sanções muito mais comuns, já que o presidente teria de arcar com o custo político de cancelar uma sanção já aprovada pelo USTR e provavelmente defendida por interesses privados. A outra mudança foi a famigerada "Seção Super 301", criada por causa da preocupação com os excessivos déficits comerciais. A medida ordenava ao USTR elaborar, em prazo de tempo estipulado, uma lista de países que ofereciam barreiras injustas aos produtos norte-americanos e cuja remoção era "prioritária" para os interesses comerciais dos EUA. Com base nesta lista, a Super 301 ordenava então que se procedesse a negociações bilaterais com os países citados para remover as barreiras; ou, caso a tentativa não fosse bem sucedida, que se considerasse a aplicação de sanções às exportações daquele país para os Estados Unidos.

A "Super Seção 301" trouxe consigo uma importante novidade. Seu foco, diferentemente das tradicionais medidas antidumping, não es- 
tava nas exportações dos países para os EUA, mas, sim, nas barreiras existentes contra os produtos exportados pelos EUA para o mundo, fundamentalmente para o Japão, que vinha acumulando grandes superavits comerciais e ganhando terreno no comércio mundial. ${ }^{19}$

A Rodada Uruguai seguiu, pois, em um contexto em que a principal potência econômica mundial indicava que faria claramente uso de seu "estoque de poder" para levar adiante seus interesses no processo negociador multilateral. Em dezembro de 1988, na reunião ministerial de Montreal, acordos preliminares foram alcançados em produtos tropicais, têxteis, propriedade intelectual, salvaguardas, melhoria no mecanismo de solução de controvérsias, além de um acordo-base na área de serviços. No entanto, o impasse na área agrícola, que se colocou como tema mais complexo desde o início das negociações, continuou. $^{20}$

As negociações agrícolas, embora o Grupo de Cairns ${ }^{21}$ tenha tentado participar de forma ativa, tomaram forma de discussão bilateral, entre os EUA e a Comunidade Européia, sobre o processo de liberalização do comércio desse setor e a redução dos subsídios internos. Os EUA mantiveram uma posição mais agressiva em relação a esse tema, tendo em mente a possibilidade de aumentar suas exportações agrícolas para o velho continente, enquanto a Europa defendia firmememente sua política de proteção e subsídios. A Europa comunitária barganhava, pois, com os EUA, o acesso a mercados em troca do compromisso americano de não questionar sua Política Agrícola Comum (PAC) no GATT.

Somente em 1992 a agricultura propiciou o encaminhamento da Rodada Uruguai. Os EUA e a Comunidade Européia estabeleceram o Blair House Accord, no qual existia a Cláusula da Paz, em que se determinava a inclusão das disciplinas agrícolas até então negociadas pelas grandes potências, ficando as demais partes contratantes do GATT impedidas de mover qualquer ação acerca de eventuais distor- 
A Ordem Econômico-Comercial Internacional: Uma Análise da Evolução do Sistema...

ções do comércio agrícola no sistema de solução de controvérsias até 2003. Destarte, as demandas do Grupo de Cairns relacionadas à diminuição substancial dos subsídios, preços administrados e aumento das importações não foram consideradas.

Depois de idas e vindas, as negociações da Rodada Uruguai foram finalmente concluídas em dezembro de 1993, em Genebra. Permaneceram, contudo, em aberto, algumas questões mais controversas, para as quais não se conseguiu "consenso" para fechar as negociações dentro da Rodada, como aquelas relativas ao comércio de produtos audiovisuais, à abertura do setor financeiro, a cláusulas sociais e ambientais, tendo as partes contratantes assumido o compromisso de continuar as discussões a respeito nos anos seguintes.

Em abril de 1994, os representantes das partes contratantes do GATT assinam a Ata Final da Rodada Uruguai, em Marraqueche. Provavelmente, a principal novidade trazida pela Ata foi a criação, em bases concretas, da Organização Mundial do Comércio (OMC), primeira instituição, de fato, responsável pelo trato das questões relativas ao comércio internacional. Fechava-se, assim, uma lacuna nunca muito bem preenchida na ordem internacional do pós-guerra, quando a OIC não entrou em funcionamento. ${ }^{22}$ Sobre os resultados finais da Rodada Uruguai, Lampreia (1995, p. 247) coloca:

O conjunto de textos de instrumentos legais negociados desde o lançamento da Rodada, em setembro de 1986, apresenta-se na Ata Final sob a forma de anexos ao Acordo que cria a Organização Mundial de Comércio (WTO), que não fora prevista em Punta del Este, mas cuja constituição foi julgada necessária para fins de abrigar, dentro de uma única moldura institucional: o Acordo Geral sobre Tarifas e Comércio, tal como modificado pela Rodada Uruguai (GATT); todos os acordos e arranjos concluídos desde 1947 sob os auspícios do 
mesmo GATT; e os resultados completos da recém-concluída Rodada.

De forma resumida, os principais resultados da última Rodada de negociações do velho GATT foram os seguintes: ${ }^{23}$ 1) acordou-se um corte médio nas tarifas internacionais, de $37 \%$; 2) no que concerne aos produtos industrializados, os países desenvolvidos concordaram em reduzir em $49 \%$ suas tarifas (de 6,3\% para 3,8\%, em média); 3 ) o tema agrícola foi finalmente inserido no SMC, sendo o Acordo sobre Agricultura (no qual normas e compromissos concernentes ao acesso a mercados, ajuda interna e subsídios às exportações foram estabelecidos) um importante marco para as negociações agrícolas na OMC. Além disso, foi acordada a tarificação de todas as barreiras não tarifárias sobre mais de $30 \%$ da produção agrícola, devendo os cortes sobre as tarifas resultantes ser de $36 \%$, para os países desenvolvidos, e de $24 \%$, para aqueles em desenvolvimento, em um período de seis e dez anos, respectivamente, a partir de 1995; 4) o setor de têxteis também foi incorporado ao SMC, devendo o Acordo Multifibras ser eliminado em dez anos, até $2005 ;{ }^{24}$ 5) ocorreu uma ampliação das linhas alfandegárias consolidadas no SMC, de 78\% para $99 \%$, no caso dos países desenvolvidos, e de $21 \%$ para $73 \%$, relativamente aos países em desenvolvimento, ${ }^{25} 6$ ) o setor de serviços também foi inserido no sistema, sendo acordado um código de regulamentação para o setor, o Acordo Geral sobre Comércio de Serviços (em inglês, General Agreement on Trade in Services (GATS)); 7) negociou-se também o Acordo sobre os Direitos de Propriedade Intelectual Relacionados com o Comércio (em inglês, Trade Related Intellectual Property Rights (TRIPS)); 8) houve um aprimoramento dos mecanismos de defesa comercial, por meio do Acordo sobre Salvaguardas e do Acordo sobre Subsídios e Medidas Compensatórias; e, finalmente, 9) criou-se um novo sistema de solução de controvérsias comerciais, essencial como mecanismo efetivo de enforcement da OMC. 
A Ordem Econômico-Comercial Internacional: Uma Análise da Evolução do Sistema...

Quase cinqüienta anos depois da tentativa de criação da natimorta OIC, o mundo comercial construía as bases, pela via multilateral, para a edificação de uma "nova" ordem comercial internacional, fundamentada no direito e com mecanismos que davam caráter impositivo às decisões tomadas multilateralmente. Embora seja possível que se faça uma relativização do poder efetivo da OMC enquanto marco jurídico internacional, é ululante a importância do papel que tal instituição veio a desempenhar, desde a sua criação, em um cenário internacional marcado pelo incremento substancial das trocas comerciais.

\section{Da Criação da OMC à Rodada do Desenvolvimento}

Antes de realizarmos uma análise das modificações ocorridas no SMC com a entrada em cena da OMC, assim como de sua trajetória durante a última década do século XX, é interessante que façamos uma avaliação honesta, ainda que relativamente rápida e superficial, dos impactos que o processo de liberalização comercial pela via multilateral ajudou a gerar sobre os fluxos mundiais de comércio, auxiliando, desse modo, o crescimento da economia mundial.

O Gráfico 1 nos traz uma clara amostra da trajetória de crescimento do comércio e produção mundiais de bens. Tomando o ano de 1950 como ano-base, observaremos que o crescimento do volume das exportações mundiais de bens tenderá a manter um crescimento maior do que aquele ocorrido no volume da produção mundial de bens. Tal diferença entre o crescimento do comércio e a produção mundial começou a se tornar mais evidente nas décadas de 1970 e 1980. Contudo, é a partir da década de 1990 que a diferença entre o crescimento observado no comércio de bens e aquele da produção dos mesmos será alargada de forma significativa. 
Ivan Tiago Machado Oliveira

\section{Gráfico 1}

Crescimento do Volume da Produção e Exportação Mundiais de Bens $(1950-2004) / 1950=100$

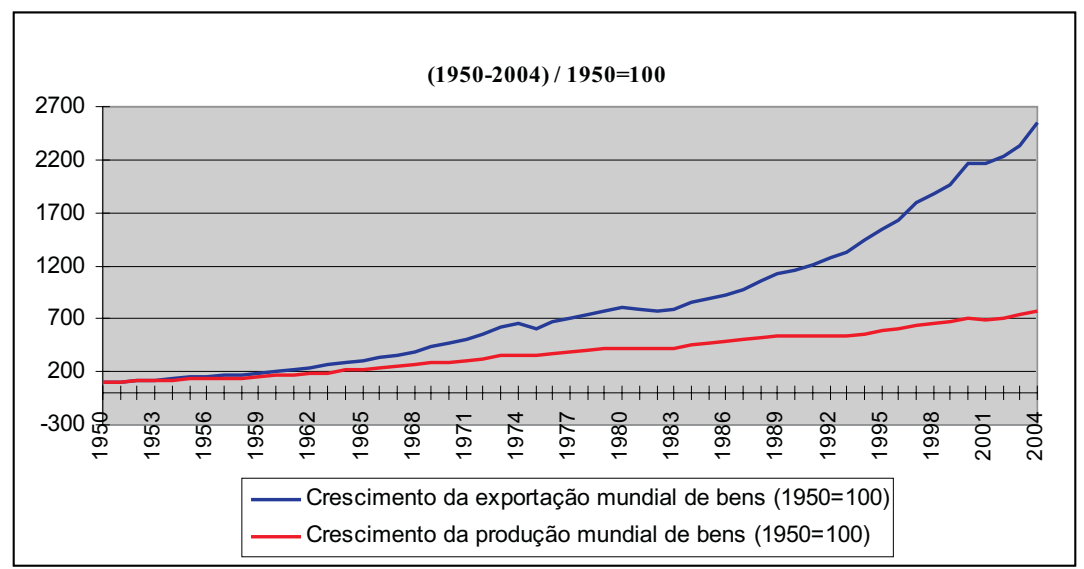

Fonte: OMC (2005b).

Acreditamos que um conjunto de fatores complementares deva ser levado em conta quando da análise das estatísticas acima apresentadas, entre eles o papel desempenhado pelo GATT na retirada dos gravames ao comércio internacional. Evidentemente as políticas de recuperação econômica do pós-guerra, de cunho fundamentalmente keynesiano, tiveram importante impacto na geração de renda e comércio no mundo. Entretanto, vale a pena lembrar que a queda progressiva das barreiras aos produtos industrializados, negociada multilateralmente, acabou ampliando as áreas de contato econômico-comercial entre as nações do mundo, principalmente entre a Europa e os EUA, em um primeiro momento. ${ }^{26}$

Ademais, especialmente na década de 1990, quando os efeitos da Rodada Uruguai começam a ser sentidos, as iniciativas minilateralistas (tanto bilaterais quanto regionais) de realização de acordos visando à liberalização do comércio internacional, seguidas por diversos países (dentre eles os EUA), vieram a auxiliar no rigoroso incremento das trocas internacionais. O que o Gráfico 1 deixa claro é que 
A Ordem Econômico-Comercial Internacional: Uma Análise da Evolução do Sistema...

uma parte cada vez mais significativa do produto mundial passou a ser gerado pelas exportações, denotando com evidência o aumento da interdependência econômico-comercial no mundo.

Falando de regionalismo, é importante relembrar que tais acordos minilateralistas sempre foram identificados como sendo um desafio ao SMC. Para uns, o regionalismo poderia vir a ferir a tendência globalizante do capitalismo, observada de forma mais clara no momento atual, e a descaracterizar o processo multilateral de liberalização comercial. Para outros, o regionalismo é visto como auxiliar no processo de abertura comercial no mundo. De toda forma, como ressalta Paulo Roberto de Almeida (2005, p. 3), é fato que:

A construção normativa do sistema multilateral de comércio registrou, de certo modo, uma evolução paradoxal. De um lado, houve o reforço dos princípios tradicionais de nação mais favorecida, de tratamento nacional, de reciprocidade, de transparência e de igualdade de direitos e de obrigações, este último temperado parcialmente pelo tratamento diferencial e mais favorável para as partes contratantes menos desenvolvidas. De outro, ocorreu o aprofundamento e a disseminação dos esquemas minilateralistas e dos arranjos geograficamente restritos, ofendendo a primeira dessas cláusulas, a de NMF.

É claro que o regionalismo nãoé, fundamentalmente, um movimento atual. O próprio Benelux, criado em 1947, e a Comunidade Européia, em 1957, além de diversos mecanismos de integração regional criados por países em desenvolvimento na década de 1960, atestam tal fato. Contudo, a última década do século passado será marcada pela expansão gigantesca desse tipo de acordo comercial entre nações. Segundo dados da OMC, apresentados por Oatley (2003, p. 22), existiam em vigor, em 2001, aproximadamente 134 acordos regionais de comércio. Desse total, noventa foram assinados entre os anos 1991 e 
2001. ${ }^{27}$ Assim, como conclui Paulo Roberto de Almeida (2005) ao falar dos acordos regionais de comércio disseminados por toda a América (a exemplo do North American Free Trade Agreement (NAFTA)), do Mercosul, da Comunidade Andina de Nações (CAN) etc.):

Esses exemplos americanos, ao lado da estratégia assistencialista desenvolvida pela UE [União Européia] em direção da clientela periférica dos países de menor desenvolvimento relativo - os PMDRs, do chamado grupo ACP [países da África, Caribe e Pacífico]-, configuram, portanto, a confirmação cabal de que o multilateralismo atual tem de conviver com um regionalismo disforme, oportunista e basicamente disfuncional em relação aos princípios do sistema econômico multilateral definido no imediato pós-Segunda Guerra. Provavelmente ele terá de enfrentar uma longa travessia do deserto antes de reencontrar terreno mais favorável para seu florescimento e expansão. (ALMEIDA, 2005, p. 12).

É nesse contexto que entra em atividade, em 1995, a Organização Mundial do Comércio (OMC), institucionalizando a regulação comercial mundial. A OMC tem como princípios basilares aqueles mesmos que davam suporte ao "velho" SMC, sob os auspícios do GATT 47, quais sejam: não-discriminação (Cláusula da NMF), reciprocidade e tratamento nacional. Além disso, o quadro legal que sustenta o SGP foi mantido no "novo" sistema.

Entre as funções capitais da OMC está a de ser o organismo administrador, tanto de acordos multilaterais, como o GATT 94, GATS, TRIPS, quanto dos plurilaterais, relacionados ao comércio de aeronaves civis, compras governamentais, comércio e produtos lácteos e de carne bovina. Ademais, a Organização serve como um fórum permanente para negociações multilaterais internacionais e também 
A Ordem Econômico-Comercial Internacional: Uma Análise da Evolução do Sistema...

como organismo imbuído de capacidade jurídica para a resolução de desavenças comerciais entre seus membros, por meio do Órgão de Solução de Controvérsias. É justamente o maior poder efetivo, fundamentado no Direito Internacional, do sistema de resolução de conflitos existente na OMC que se coloca como ponto fundamental de distinção, relativamente ao "velho" sistema GATT. ${ }^{28}$ Tal aspecto traz consigo a conformação de um sistema caracterizado por ser mais rule-oriented (orientado por regras), dando maior efetividade e legitimidade ao SMC.

No entanto, vale frisar que, mesmo com um sistema de solução de controvérsias mais eficaz e poderoso, por vezes será observado que principalmente as grandes potências terão algum espaço, ainda que "ilegal", para o uso de seus "estoques de poder" no descumprimento de compromissos assumidos multilateralmente, o que denota a complexidade da interação entre as nações, quando tentam construir regras gerais e objetivas para gerir suas trocas materiais. Sobre esse fato, Lima (2004, p. 36) coloca:

Os países não se desfazem da sua autonomia voluntariamente e as regras que compõem o sistema raramente são auto-executáveis. Em vez de criar uma lei para controlar o comportamento dos Estados, as instituições internacionais servem para estabelecer expectativas a respeito do comportamento de outras nações.

A OMC tem, no topo da estrutura funcional, a Conferência Ministerial, na qual os representantes de todos os seus membros se reúnem pelo menos uma vez a cada dois anos, podendo deliberar sobre qualquer assunto relacionado aos acordos multilaterais de comércio. No intervalo das reuniões ministeriais, os trabalhos da OMC são realizados por diversos órgãos, sendo o principal deles o Conselho Geral, ao qual estão subordinados o Conselho para Comércio de Mercadorias, o Conselho para Direitos de Propriedade Intelectual Relacionados 
com o Comércio e o Conselho para Comércio de Serviços. ${ }^{29}$ Aos diversos conselhos que estão subordinados ao Conselho Geral, por sua vez, ficam subordinados numerosos outros grupos de trabalho e comitês. Ademais, existem outros quatro comitês responsáveis por assuntos relacionados com as temáticas: comércio e meio ambiente, comércio e desenvolvimento, restrições de balanço de pagamentos, e administração e orçamento da OMC.

Na primeira reunião ministerial da OMC, realizada em Cingapura em 1996, foram iniciadas negociações sobre novos temas dentro da agenda da Organização, como comércio e investimento, comércio e competição, transparência nas compras governamentais e facilitação de comércio, seguindo o que fora acordado ao fim da Rodada Uruguai. Já na reunião de Cingapura, por iniciativa liderada pela UE, foi proposto o lançamento de uma nova Rodada de negociações multilaterais, que tivesse como foco os temas acima referidos. Entretanto, a oposição consistente de diversos países em desenvolvimento, entre eles o Brasil, fez com que tal proposta fosse adiada. Ademais, os países em desenvolvimento levaram a cabo um conjunto de proposições que visava tentar resolver os muitos problemas que ainda persistiam relativamente à implementação do acordado na Rodada Uruguai, principalmente naqueles setores que mais lhes eram benéficos, como o agrícola e o têxtil. ${ }^{30}$

Reunidos em Seattle, nos EUA, em 1999, os ministros dos países-membros da OMC tentaram pavimentar o caminho para o lançamento da então chamada Rodada do Milênio. Contudo, por fatores diversos, impasses foram criados e a reunião resultou em um retumbante fracasso. ${ }^{31}$ Como elementos capitais na geração de tal fracasso, podemos destacar a falta de efetiva motivação política e de consenso, entre os atores internacionais mais poderosos, quanto à agenda a ser negociada. Por um lado, os EUA tentavam avançar na abertura do setor de serviços, movimento iniciado na década de 1980, no qual se observa a liberalização dos serviços como mecanismo a ser 
A Ordem Econômico-Comercial Internacional: Uma Análise da Evolução do Sistema...

usado na tentativa de melhora das contas externas do país. Já o Japão e a Europa, sabendo que uma nova Rodada puxaria necessariamente o tema agrícola para o centro das discussões, queriam ampliar as negociações na área de investimentos e concorrência, temas que lhes eram mais convenientes. ${ }^{32}$

Cabe aqui apresentar, de forma sucinta, algumas modificações ocorridas na posição da diplomacia econômica brasileira no decorrer da década de 1990, relativamente ao SMC. As próprias transformações da economia, com a abertura comercial iniciada no início dos anos 1990, atuaram sobre o posicionamento do país diante das negociações internacionais. A diplomacia toma um tom mais liberal, não deixando de ter, pelo menos retoricamente, o objetivo primordial de ser elemento auxiliar na busca pelo desenvolvimento econômico brasileiro. A construção do Mercosul também influenciou o trato diplomático do Brasil no mundo, passando o país a ter de harmonizar interesses dentro do bloco para seguir adiante nas negociações de liberalização pela via multilateral.

É importante lembrar que muitos países em desenvolvimento continuam a manifestar freqüente descontentamento com as mudanças só marginais nas normas internacionais de comércio relativas aos setores em que possuem maior competitividade, desde o GATT-1947 até a atualidade. Mesmo existindo um arcabouço de medidas que busca dar maior proteção aos países em desenvolvimento dentro da OMC, a insatisfação torna-se clara e fundamentada quando os principais produtos exportados pelos mesmos encontram significativas barreiras de entrada nos mais diversos mercados mundiais, sejam elas ligadas a picos e escaladas tarifárias, ou a quotas, barreiras fitossanitárias etc.

Para alguns, como Gonçalves (2003a), a falta de democracia no SMC leva à elaboração de agendas que interessam aos países desenvolvidos. Assim, muitos vêem a OMC como uma instituição usada pelos 
países fortes como instrumento de política externa. Destarte, os países em desenvolvimento vêm apresentando especial interesse em modificar, no âmbito da OMC, normas e fundamentos das negociações, tendo em vista um maior foco no desenvolvimento, o que denota uma volta aos fundamentos da Carta de Havana, pensada há quase cinqüenta anos atrás.

Tentando conciliar os interesses de países em desenvolvimento (Grupo de Cairns, entre outros) com aqueles dos países desenvolvidos (EUA, os da UE e Japão), ocorre em Doha, no Catar, a quarta reunião ministerial da OMC. É importante lembrar que os trabalhos político-diplomáticos em Doha, em novembro de 2001, ocorreram em uma conjuntura em que os traumas dos ataques terroristas aos EUA estavam muito presentes, e a economia mundial não andava muito bem, existindo grande incerteza acerca do seu desempenho futuro. Destarte, o mundo pressionava pela emissão de sinais positivos pela $\mathrm{OMC}$, tendo em vista que um novo fracasso nas negociações em Doha poderia trazer mais trevas ao cenário mundial, já bastante negativo. Ao final do encontro, a Declaração Ministerial de Doha lançou um documento repleto de "ambigüidades construtivas", que colocavam a questão das concessões às preocupações dos países em desenvolvimento como ponto primordial a ser discutido. Estava lançada a nova Rodada de negociações multilaterais da OMC: a Rodada do Desenvolvimento.

\section{A Rodada Doha: Expectativas, Desafios e Oportunidades}

O SMC, seguindo o processo histórico-evolutivo descrito anteriormente, chega ao século XXI com uma nova roupagem, mais robusta e efetiva na condução da regulação internacional do comércio. A OMC tornou-se uma instituição central enquanto componente de suporte à atual onda de globalização. Ademais, neste início de século, a 
A Ordem Econômico-Comercial Internacional: Uma Análise da Evolução do Sistema...

luta pelo desenvolvimento das regiões mais pobres do planeta também passou a ecoar de forma mais relevante em instituições internacionais como a OMC. Observa-se, aqui, certa volta às demandas dos países mais pobres, colocadas em meados do século passado, quando das negociações acerca da Carta de Havana que criava a OIC.

Conceito-chave que norteou as ações do mundo econômico nos mais diversos países durante boa parte da segunda metade do século XX, estando marginalizado nas últimas décadas do mesmo pelas crises que assolaram o mundo, o desenvolvimento volta à cena internacional no início de século XXI, buscando fazer com que uma parte cada vez maior da população mundial tire proveito dos benefícios trazidos com a, por vezes tão vilipendiada, globalização.

É nesse contexto que os membros da OMC lançam a atual Rodada de negociações comerciais multilaterais, a Rodada Doha. Como colocado ao findar a seção anterior, a retórica desenvolvimentista em prol dos países menos avançados foi a base de lançamento da Rodada, apontando para o tema agrícola como pilar fundamental das negociações. Não obstante a liberalização do comércio agrícola seja considerada como elemento central da Rodada, novas negociações acerca de diversos outros temas (como serviços, produtos não agrícolas, propriedade intelectual, investimentos, comércio eletrônico etc.) foram também lançadas em Doha, buscando uma óbvia harmonização de interesses entre os países em desenvolvimento e os países desenvolvidos.

A importância dada aos interesses dos países em desenvolvimento na atual Rodada de negociações da OMC, pelo menos retoricamente, pode ser vislumbrada de forma clara no seguinte excerto da Declaração Ministerial de Doha:

O comércio internacional tem condições para desempenhar um importante papel na promoção do desenvolvimento econômico e na dimi- 
nuição da pobreza. Reconhecemos a necessidade de todos os nossos povos se beneficiarem do aumento de oportunidades e da prosperidade gerados pelo sistema multilateral de comércio. [...] continuaremos nossas iniciativas concretas, planejadas para garantir que os países em desenvolvimento, e especialmente os menos desenvolvidos dentre eles, assegurem a sua parcela de participação no crescimento do comércio mundial, proporcional às necessidades de suas economias em expansão. Nesse contexto, acesso favorecido ao mercado, regras equânimes, assistência técnica com financiamento sustentável e objetivos bem formulados, e programas de capacitação têm importante função a cumprir. (CONFERÊNCIA MINISTERIAL DA ORGANIZAÇÃO MUNDIAL DO COMÉRCIO, 2001, p. 1).

Desde a IV Conferência Ministerial da OMC, em Doha, quando o mandato negociador sobre os variados temas foi acordado, as negociações tomaram corpo de forma permanente em Genebra, tendo ocorrido eventos posteriores que buscaram diminuir as divergências entre posicionamentos dos países, relativamente aos temas negociados. Em um primeiro momento, pode-se citar a V Conferência Ministerial, ocorrida em Cancun, em setembro de 2003, fracassada pela falta de entendimento entre os países em desenvolvimento e seus pares desenvolvidos, sobre a liberalização agrícola e ditos temas de Cingapura. Vale ressaltar que, do ponto de vista dos interesses brasileiros na Rodada (focados no tema agrícola), a Conferência em Cancun trouxe à tona a participação do G-20 como interlocutor importante nas negociações.

As negociações comerciais multilaterais ficaram relativamente estagnadas até meados de julho de 2004, quando se conseguiu chegar a um acordo para a retomada efetiva das negociações (The July 2004 package). As negociações prosseguiram por um ano e meio até a VI 
A Ordem Econômico-Comercial Internacional: Uma Análise da Evolução do Sistema...

Conferência Ministerial da OMC, realizada em Hong Kong em dezembro de 2005. Nesse encontro, algumas arestas foram aparadas em relação aos temas mais controversos e um progresso relativo foi obtido em áreas específicas, como na dos subsídios à exportação agrícola, que devem ser extintos completamente até 2013. Entrementes, muito ainda restava de controverso e não acordado em temas muito importantes para a Rodada, como aqueles relacionados à agricultura (acesso a mercado e apoio interno), serviços e bens não agrícolas. Ademais, na Conferência de Hong Kong, estabeleceu-se um novo cronograma para as negociações em 2006, que seria mais uma vez desrespeitado.

Não obstante tenha ocorrido alguma aproximação entre as propostas dos principais grupos interessados no tema agrícola desde o início das negociações, o mesmo continuou a ser tanto o foco principal do mandato negociador de Doha, quanto o elemento mais controverso e de complexa negociação da Rodada. Os EUA e a Europa Comunitária continuam bastante reticentes quanto aos seus pontos mais sensíveis na negociação agrícola. Por um lado, a UE pressiona os norte-americanos por uma proposta mais agressiva em relação ao apoio interno. Por outro, os EUA colocam que, sem uma proposta européia de liberalização efetiva do acesso ao seu mercado no setor agrícola, o progresso das negociações não pode ser materializado de forma mais rápida. Os países do G-20, de outro lado, buscam maior abertura dos mercados agrícolas dos países desenvolvidos para seus produtos, mas são um tanto relutantes na abertura de setores industriais e de serviços. Tudo isso sem falar em certa esquizofrenia do próprio G-20, em que existem desde países com posicionamentos agressivos em todas as frentes agrícolas, como o Brasil, a economias que buscam posicionamentos claramente protecionistas, como a Índia. ${ }^{33}$

Tais posicionamentos discrepantes entre os principais atores das negociações agrícolas na OMC levaram a Rodada Doha a mais um im- 
passe e à paralisação por tempo indeterminado das negociações, em meados de 2006.

É importante frisar, por fim, que, mesmo que o resultado objetivo obtido ao fim da Rodada Doha, que provavelmente terá as negociações retomadas em um futuro não muito distante, não seja o first best, os países-membros da OMC, principalmente os em desenvolvimento, devem observar atenciosamente a importância da defesa do SMC fundamentado no Direito Internacional como instrumento que possibilita certa restrição ao exercício do poder arbitrário em âmbito mundial. Além do mais, os países em desenvolvimento necessitam estar atentos às oportunidades e aos desafios gerados, com as negociações na OMC, ao desenvolvimento econômico (inter)nacional, o qual necessariamente passa por uma inserção econômica ativa neste nosso mundo cada vez mais interdependente.

\section{Notas}

1. Dados apresentados por Sato (2001, p. 9).

2. É interessante notar aqui que, quando das negociações do GATT em 1947, ficou acordada a possibilidade do estabelecimento de zonas de livre-comércio e de uniões aduaneiras, tendo por base o modelo e a experiência do Benelux, nascente no período (artigo XXIV do Acordo Geral). Esse fato irá gerar impedimentos legais ao início do processo de integração latino-americano, em que uma área de livre-comércio teve de ser criada desde o princípio (Aliança Latino-Americana de Livre Comércio (ALALC), em 1960) e não uma zona de preferências comerciais, como parecia mais adequado, dado o grau de desenvolvimento das economias da região, o que acabou por resultar em insucessos significativos.

3. Para uma análise aprofundada acerca do enforcement do sistema multilateral, desde o GATT/47 até os dias atuais com a OMC, ver Lima (2004).

4. Vale aqui frisar que tanto o princípio da NMF quanto o da reciprocidade já haviam sido utilizados em acordos feitos na segunda metade do século XIX pe- 


\section{A Ordem Econômico-Comercial Internacional:}

Uma Análise da Evolução do Sistema...

los EUA e por muitos países europeus, conformando um verdadeiro SMC, à sua época, que seria destruído em 1914 com a Primeira Guerra.

5. Até a Rodada Dillon do GATT, ocorrida entre 1960 e 1961, as negociações eram feitas em bases bilaterais, indentificando-se os principais fornecedores de cada produto negociado. Depois de elaborada uma lista de pedidos e ofertas, um acordo era buscado, pautado na reciprocidade das concessões e, por meio do princípio da NMF, tais concessões eram estendidas para os demais países que faziam parte do Acordo Geral. Os EUA viam o bilateralismo gattiano como benéfico, tendo em vista que a acomodação de interesses internos, muitas vezes conflitantes, tornava-se menos complexa.

6. Tanto países em desenvolvimento quanto países desenvolvidos fizeram uso, por vezes continuado, de tais mecanismos excepcionais do GATT. O Brasil, por exemplo, utilizou-se principalmente do artigo XVIII para promover sua industrialização, via substituição de importações, sem ferir a legalidade do SMC, do qual fazia parte.

7. Dados apresentados por Paulo Roberto de Almeida (2004, p. 119).

8. É importante lembrar que o mundo passava por mudanças geopolíticas relativamente importantes com o movimento dos não-alinhados, que se colocaram como forças protagonistas nas transformações da ordem comercial de então, como pode ser observado na própria criação do G-77 e da UNCTAD.

9. Vale mencionar que, por vezes, o Congresso dá ao Executivo o poder de negociar acordos comerciais sob determinadas condições, o que faz com que os congressistas possam considerar as demandas de seus eleitores por mais proteção sem que isso ameace o processo negociador internacional. Tal delegação de poder negociador ao Executivo é comumente chamada de fast track.

10. Pela legislação comercial vigente nos EUA, isto significa que qualquer tratado comercial, como qualquer outra lei, deve obter a aprovação da maioria das duas casas do Congresso, que pode, a não ser em casos especiais, propor emendas e interpretações aos tratados que lhe são submetidos. [Nota no original].

11. Para uma análise eloqüente e com riqueza de detalhes sobre as relações Norte-Sul nos foros econômicos multilaterais, ver Bahadian (1992). O autor analisa os debates na ONU a respeito das negociações sobre o Código de Práticas Comerciais Restritivas, estendendo-se ainda aos Códigos de Conduta para Transferência de Tecnologia e de Empresas Transnacionais.

12. Dados apresentados por Paulo Roberto de Almeida (2004, p. 119). 


\section{Ivan Tiago Machado Oliveira}

13. Vale notar que a posição norte-americana em relação aos acordos bilaterais e regionais de comércio será mantida durante a década de 1990, quando importantes iniciativas tomaram forma, como o NAFTA, Iniciativa da Bacia do Caribe, African Growth Opportunity Act, e as primeiras negociações da ALCA.

14. Na verdade, para alguns estudiosos, o que os países desenvolvidos (fundamentalmente os EUA) fizeram foi colocar os países em desenvolvimento como "bodes expiatórios" dos problemas da ordem comercial internacional.

15. Logo após a crise mexicana de 1982 , o Tesouro dos EUA ofereceu empréstimo ao Brasil, auxiliando-o no enfrentamento das condições econômicas adversas daqueles anos. Entretanto, o condicionante para tal foi justamente o Brasil não bloquear a entrada das discussões sobre o setor de serviços no GATT.

16. Uma importante observação a ser aqui realizada é a de que as posições do G-10, no qual o Brasil e a Índia se colocavam como líderes, foram, de certa maneira, marginalizadas quando do lançamento da Rodada. Foi o Acordo Colômbia-Suíça (Café au Lait), que reunia diversos países em desenvolvimento que não estavam de acordo com os posicionamentos do G-10 e era apoiado pelos EUA, que traçou as bases de lançamento da Rodada Uruguai, em competição com o documento construído pelo G-10.

17. Vale aqui notar que, ao final da Rodada Uruguai, as negociações do comércio de bens e de serviços haviam se fundido, resultando no pacote global da Rodada sendo tratado como um single undertaking.

18. Cabe frisar que, embora seja possível encontrar antecedente jurídico na Seção 2252 da Lei do Comércio de 1962, a famosa Seção 301 da Lei de Comércio dos EUA apareceu pela primeira vez na Lei de 1974, concedendo ao presidente poder para iniciar ações retaliatórias contra práticas comerciais "não razoáveis" e "injustificáveis". Desde então, a Seção 301 foi sendo ampliada, dando cada vez maior poder ao Executivo para fazer uso de medidas claramente protecionistas.

19. O Brasil, juntamente com a Índia e o Japão, entrou na primeira lista negra de "prioridades" elaborada pelo USTR a partir da Lei de 1988. Brasil e Índia eram considerados alvos politicamente fáceis, por serem economias relativamente pequenas e possuírem grandes barreiras comerciais. O Brasil saiu da lista negra quando da abertura comercial unilateral promovida durante o governo Collor. Em relação ao Japão, as pressões sobre o mesmo fizeram com que os japoneses cedessem e concordassem com a Structural Impediments Initiative norte-americana de 1989, na qual se iniciou a negociação da redução de barreiras japonesas às exportações dos EUA. 


\section{A Ordem Econômico-Comercial Internacional:}

Uma Análise da Evolução do Sistema...

20. Em abril de 1989, foi alcançado um primeiro acordo relativo aos objetivos gerais para o tema agrícola.

21. O Grupo de Cairns surgiu da interação iniciada entre países em desenvolvimento, entre eles o Brasil, no infrutífero G-10, e alguns países desenvolvidos, tendo como objetivo comum a abertura comercial na área agrícola. $\mathrm{O}$ grupo reúne, pois, países que são grandes produtores agrícolas tanto do grupo dos desenvolvidos (Austrália, Nova Zelândia e Canadá), quanto daqueles em desenvolvimento. Vale ressaltar que a diplomacia brasileira teve importante participação na constituição do Grupo de Cairns, não obstante o mesmo não tenha tido muita vez e voz nos resultados concretos relativos à agricultura no GATT.

22. Vale lembrar que, inicialmente, os países em desenvolvimento mantinham uma posição relativamente cética em relação à criação de uma nova organização internacional. Contudo, tal posicionamento veio mudando ao longo da Rodada Uruguai, tendo por base a idéia, já aqui apresentada, de que um sistema com maior fundamentação legal os deixaria menos vulneráveis ao arbítrio das grandes potências.

23. Dados e informações apresentados a seguir foram baseados fundamentalmente em Rêgo (1996).

24. Vale lembrar que em 2005, com o fim do Acordo Multifibras (criado em 1974), tanto a Europa quanto os EUA começaram a ser inundados por produtos têxteis vindos principalmente da China. Tal fato levou os mesmos a negociarem acordos com os chineses, no sentido de restringir exportações chinesas de têxteis para o mercado europeu e norte-americano. É importante lembrar que o setor têxtil foi muito protegido pelos países desenvolvidos desde as primeiras décadas do pós-guerra, tendo tal proteção começado a tomar forma de um acordo plurilateral ainda na década de 1960.

25. O Brasil consolidou suas tarifas em $35 \%$, para produtos industrializados, e em 55\%, para os agropecuários, válidas a partir do ano 2000.

26. A legitimidade do SMC, sob os auspícios do GATT, advinha parcialmente do crescimento substancial do comércio internacional. Contudo, é lógico que a anuência da potência econômica mundial com o que era acordado multilateralmente tinha peso mais significativo enquanto ação legitimadora do SMC.

27. Volta à discussão, aqui, a questão do hegemom, ou hegemons. Muitos estudiosos colocam que essa tendência minilateralista existente no sistema comercial internacional atualmente adviria do "problema de liderança", no qual o exemplo dado pelas principais potências mundiais (fundamentalmente os EUA e a União Européia) nas últimas décadas reforçaria a constituição de um ambiente favorável a esses arranjos minitaleralistas mundo afora. 
28. Vale aqui colocar que outra inovação ocorrida no SMC, no pós-Rodada Uruguai, foi a criação do Órgão de Exame de Políticas Comerciais, por meio do qual são feitas análises acerca das políticas comerciais dos países-membros, servindo como mecanismo de vigilância quanto ao cumprimento dos compromissos assumidos.

29. Cabe salientar que o Conselho Geral também atua tanto como Órgão de Exame de Políticas Comerciais, quanto como Órgão de Solução de Controvérsias Comerciais.

30. Os temas ligados a questões sociais e ambientais, que deveriam ser discutidos na reunião, acabaram por ganhar atenção marginal, sem resolução aparente no curto prazo. É fato que existe uma enorme resistência, inclusive por grande parte dos países em desenvolvimento, de se incorporar normas no SMC relativas a questões sociais e ambientais, tendo por base a idéia de que alguns dos fatores geradores de suas vantagens comparativas poderiam ser contestados, em benefício de uma minoria nos países desenvolvidos.

31. Entre os possíveis fatores que engendraram o fracasso de Seattle está a pressão dos movimentos antiglobalizadores feita durante a reunião.

32. Gonçalves (2003b), em seu capítulo 2 , faz uma interessante análise sobre as principais interpretações acerca do fracasso da reunião de Seattle, bem como sobre divergências e impasses lá gerados.

33. Como líder do G-20, o Brasil tem desempenhado um papel fundamental no processo negociador agrícola, empenhando-se na árdua tarefa de buscar pontos de convergência interna que dêem sustentação ao grupo, e em não deixar que o tema agrícola venha a apresentar resultados negociados, ao fim da Rodada, que sejam puramente fundados nos interesses das grandes potências.

\section{Referências Bibliográficas}

ABREU, Marcelo de P. Brazil, the GATT and the WTO: history and prospects. Rio de Janeiro: PUC-Rio, 1998. 38 p. (Texto para discussão nº 392). Disponível em: <http://www.puc-rio.br>. Acesso em: 10 ago. 2006.

ALMEIDA, Paulo Roberto de. O Brasil e o multilateralismo econômico. Porto Alegre: Livraria do Advogado, 1999. 210 p. 
A Ordem Econômico-Comercial Internacional: Uma Análise da Evolução do Sistema...

Diplomacia comercial: de Bretton Woods e Havana à OMC. In Relações internacionais e política externa do Brasil: história e sociologia da diplomacia brasileira. 2. ed. Porto Alegre: UFRGS, 2004, p. 111-144.

Acordos minilaterais de integração e de liberalização do comércio: uma ameaça potencial ao Sistema Multilateral de Comércio. In: Negociações internacionais: mais do que produzir, é preciso saber negociar. São Paulo: American Chamber, 2005. Disponível em: <http://www.pralmeida.org > . Acesso em: 28 jan. 2006.

ARRIGHI, Giovanni. O longo século XX: dinheiro, poder e as origens de nosso tempo. Rio de Janeiro: Contraponto, 2003. 408 p.

BAHADIAN, Adhemar Gabriel. A tentativa do controle do poder econômico nas Nações Unidas: estudo do conjunto de regras e princípios para o controle das práticas comerciais restritivas. Brasília: IPRI, 1992.

BAUMANN, Renato et al. Economia internacional: teoria e experiência brasileira. Rio de Janeiro: Elsevier, 2004. 442 p.

BUENO, Clodoaldo. A política multilateral brasileira. In: CERVO, A. L. (Org.). O desafio internacional: a política exterior do Brasil de 1930 a nossos dias. Brasília: Editora Universidade de Brasília, 1994. cap. 2, p. 59-144.

CONFERÊNCIA MINISTERIAL DA ORGANIZAÇÃO MUNDIAL DO COMÉRCIO. Ministerial declaration. Genebra: OMC, 2001. 10 p. Disponível em <http://www.into.org>. Acesso em: 30 abr. 2006.

DIAS, Viviane Ventura. O Brasil entre o poder da força e a força do poder. In: BAUMANN, R. (Org.). O Brasil e a economia global. Rio de Janeiro: SOBEET, 1996. cap.4, p. 55-73.

GODINHO, Renato Domith. Os diplomatas do Capitólio: a política externa norte-americana e a influência dos grupos de pressão no Congresso dos Estados Unidos. 2005. 163 p. Dissertação (Mestrado em Diplomacia) - Instituto Rio Branco, Brasília, 2005.

GONÇALVES, Reinaldo. Globalização comercial. In: O nó econômico.

Rio de Janeiro: Record, 2003a. cap. 4, p. 97-122.

. O Brasil e o comércio internacional: transformações e perspectivas. 2. ed. São Paulo: Contexto, 2003b. 149 p. 
GUIMARÃES, Feliciano de Sá. A Rodada Uruguai do GATT (1986-1994) e a política externa brasileira: acordos assimétricos, coerção e coalizões. 2005. 195 p. Dissertação (Mestrado em Relações Internacionais) - Programa San Tiago Dantas - UNESP, UNICAMP, PUC-SP -, Campinas, 2005.

LAMPREIA, Luiz Filipe P. Resultados da Rodada Uruguai: uma tentativa de síntese. Estudos Avançados, v. 9, n. 23, p. 247-260, 1995.

LIMA, Tatiana Macedo N. GATT/OMC: uma análise institucional. 2004. 97 p. Dissertação (Pós-graduação em Economia) - Faculdade de Economia, Administração e Contabilidade, USP, São Paulo, 2004.

OATLEY, Thomas. International political economy: interests and institutions in the global economy. Londres: Longman, 2003. 432 p.

OMC. Understanding the WTO. 3. ed. Genebra, 2005a. 116 p. Disponível em: <http://www.wto.org> . Acesso em: 22 mar. 2006.

International trade statistics 2005. Genebra, 2005b. 274 p. Disponível em: <http://www.wto.org>. Acesso em: 20 set. 2006.

RÊGO, Elba C. L. Do Gatt à OMC: o que mudou, como funciona e para onde caminha o Sistema Multilateral de Comércio. Revista do BNDES, Rio de Janeiro, v. 3, n. 6, p. 3-22, dez. 1996.

RICUPERO, Rubens. Os Estados Unidos e o comércio mundial: protecionistas ou campeões do livre-comércio? Estudos avançados, São Paulo, v. 16, n. 46, p. 7-18, set./dez. 2002.

SATO, Eiiti. Mudanças estruturais no sistema internacional - a evolução do regime de comércio do fracasso da OIC à OMC, maio. 2001. Disponível em: $<$ http://www.ufrgs.br/irel>. Acesso em: 10 jun. 2006.

SEITENFUS, Ricardo A. S. Manual das organizações internacionais. 4. ed. Porto Alegre: Livraria do Advogado, 2005. 384 p.

VALLS, Lia. Histórico da Rodada Uruguai do GATT. Rio de Janeiro: UFRJ, 1997. 23 p. Manuscrito. Disponível em: <http://www.ie.ufrj.br>. Acesso em: 20 jul. 2006. 
A Ordem Econômico-Comercial Internacional: Uma Análise da Evolução do Sistema...

\section{Resumo}

\section{A Ordem Econômico-Comercial Internacional: Uma Análise da Evolução do Sistema Multilateral de Comércio e da Participação da Diplomacia Econômica Brasileira no Cenário Mundial}

O trabalho traça uma análise histórica do Sistema Multilateral de Comércio (SMC), tendo como foco a sua importância para a conformação da ordem econômica internacional do pós-Segunda Guerra Mundial. A partir de uma perspectiva analítico-evolutiva, faz-se uma apresentação do contexto internacional no qual o sistema multilateral foi gerado e identificam-se as interações entre as transformações históricas mundiais, tanto no plano político quanto no econômico, e a estruturação do Sistema Multilateral de Comércio, desde o Acordo Geral sobre Tarifas e Comércio (em inglês, General Agreement on Tariffs and Trade (GATT)) até a Organização Mundial do Comércio (OMC). Ademais, o papel desempenhado pela diplomacia econômica brasileira na construção e transformação do SMC será discutido ao longo do presente trabalho. Também são feitas considerações sobre a atual Rodada de negociações multilaterais, a Rodada Doha, e a sua relevância na ótica dos países em desenvolvimento.

Palavras-chave: GATT - OMC - Multilateralismo - Comércio Internacional - Diplomacia Econômica

\section{Abstract}

The International

Economic-Commercial Order: An

Analysis of the Evolution of the

Multilateral Trading System and

of the Involvement of the

Brazilian Economic Diplomacy in the Global Scenario

This work brings a historical analysis of the multilateral trading system, focusing on its importance to the building up of the international economic 
order, after the Second World War. From an evolutionary perspective, the international context in which the multilateral trading system was created is presented. Moreover, the interactions between world historical transformations and the development of the multilateral trading system, from GATT to WTO, are analyzed, both in political and economic points of view. Furthermore, the role played by the Brazilian economic diplomacy in building and transforming the multilateral trading system is analyzed. Some considerations are also made on the Doha Round of trade talks and its importance to the developing countries.

Keywords: GATT - WTO - Multilateralism - International Trade Economic Diplomacy 